Jerzy Bednarz, Udział biegłych sądowych w procesach o stwierdzenie nieważności małżeństwa w Sądzie Diecezjalnym w Tarnowie w latach 1945-1983, [w:] Struktura i działalność Sądu Diecezjalnego w Tarnowie w latach 1945-1983, red. Robert Kantor, Kraków 2019, s. 105-142.

DOI: http://dx.doi.org/10.15633/9788374387309.07

\author{
KS. JERZY BEDNARZ
}

Uniwersytet Papieski Jana Pawła II w Krakowie

Wydział Teologiczny Sekcja w Tarnowie

\title{
Udział biegłych sądowych w procesach o stwierdzenie nieważności małżeństwa w Sądzie Diecezjalnym w Tarnowie w latach 1945-1983
}

Działalność biegłych sądowych ${ }^{1}$ w latach $1945-1983$ była regulowana przede wszystkim przez normy zawarte w Codex Iuris Canonici z 1917

\footnotetext{
1 Pod pojęciem biegłego sądowego (znawcy, rzeczoznawcy, eksperta) rozumiano osobę, która opierając się na fachowej wiedzy w pewnej specjalności i zdobytym w tym kierunku doświadczeniu, wydawała na potrzebę sądu opinię (ekspertyzę) o istnieniu, naturze, przyczynach lub skutkach jakiegoś faktu. Biegłymi byli m.in. lekarze, psychologowie, psychiatrzy, grafologowie itp. Por. I. Noval, Commentarium Codicis Iuris Canonici, Lib. IV, De processibus, pars I, De iudiciis, Romae 1920, s. 356, n. 513; T. Bensch, Wplyw chorób umysłowych na ważność umowy małżeńskiej w prawie kanonicznym, Lublin 1936, s. 271-272; F. M. Cappello, Summa iuris canonici in usum scholarum, Vol. III, De processibus, delictis et poenis, Romae 1948, s. 218, n. 261; F. X. Wernz, P. Vidal, Ius canonicum ad Codicis normam exactum, Vol. vi, De processibus, Romae 1949, s. 445, n. 489; M. Lega, Commentarius in iudicia ecclesiastica iuxta Codicem Iuris Canonici, Vol. II, Romae 1950, s. 744-745; M. Conte a Coronata, Compendium iuris canonici. Ad usum scholarum, Vol. II, Romae 1950, s. 274, n. 1930; F. Bączkowicz, Prawo kanoniczne. Podręcznik dla duchowieństwa, t. 3, wyd. 3, Opole 1958, s. 108; S. Biskupski, Prawo małżeńskie Kościoła rzymskokatolickiego, t. 2, Proces matżeński, Olsztyn 1960, s. 265-266; T. Pawluk, Kanoniczne procesy szczególne, Warszawa 1971, s. 280. Komentatorzy Kodeksu pio-benedyktyńskiego i autorzy podręczników prawa kanonicznego zwracali uwagę na różnicę między świadkiem a biegłym. Ten pierwszy jedynie poświadcza to, co dostrzegł zmysłami (co widział i słyszał). Biegły natomiast oprócz stwierdzenia faktu wydaje o nim opinię drogą rozumowania, przy zastosowaniu
} 
roku w can. 1792-1805². Zawierają one ogólne normy na temat biegłego sądowego. Ponadto kodeks w can. 1976-1982 $2^{3}$ mówił o zastosowaniu opinii biegłych w procesach małżeńskich, które miały uwzględniać kodeksowe normy ogólne odnośnie do biegłego sądowego, umieszczone w can. 1792-1805.

Biegli mieli być także powoływani w procesach beatyfikacyjnych ${ }^{4}$, $\mathrm{w}$ których ich rola sprowadzała się przede wszystkim do sprawdzenia dokumentów historycznych ${ }^{5} \mathrm{i}$ analizowania ewentualnego $\mathrm{cudu}^{6}$.

Celem niniejszego artykułu jest ogólne zaprezentowanie działalności biegłych sądowych w procesach małżeńskich w Sądzie Diecezjalnym

metod właściwych jego specjalności wyprowadza wnioski o przyczynach faktu, jego naturze i skutkach. Por. M. Lega, Commentarius in iudicia ecclesiastica..., dz. cyt., s. 744-745; L. Miguélez Domínguez, S. Alonso Morán, M. Cabreros de Anta, Código de derecho canónico y legislación complementaria. Texto latino i versión castellana, con jurisprudencia y comentarios, Madrid 1952, s. 670-671; S. Biskupski, Prawo małżeńskie Kościoła rzymskokatolickiego, dz. cyt., s. 266.

2 Por. Codex Iuris Canonici [dalej: CIC 1917], Lib. Iv, De Processibus, Pars I, De Iudiciis, Sectio I, De Iudiciis in genere, Titulus x, De probationibus, Caput III, De peritis.

3 Por. CIC 1917, Lib. IV, De Processibus, Pars I, Sectio II, De peculiaribus normis in certis quibusdam iudiciis servandis, Titulus xx, De causis matrimonialibus, Caput Iv, De probationibus, art. II, De inspectione corporali; F. X. Wernz, P. Vidal, Ius canonicum ad Codicis normam exactum, Vol. v, Ius matrimoniale, Romae 1946, s. 911-912.

4 „Tribunal in ipsa prima sessione eligat notarium, eius adiunctum, peritum, si casus ferat, et cursorem, ac de eiusmodi electione fidem faciat notarius Curiae". CIC 1917, can. $2093 \$ 2$. W procesach beatyfikacyjnych i kanonizacyjnych powinno być obecnych przynajmniej 2 biegłych. „Cum peritorum opera est necessaria: $1^{\circ}$ Periti sint saltem duo, quorum alter alteri sit ignotus, salvo praescripto n. $4^{\prime}$. CIC 1917, can. $20311^{\circ}$. „Periti seorsum singuli ad peritiam deveniant, nisi ex iusta causa iudex, assentiente promotore fidei, permittat ut ii simul peritiam instituant". CIC 1917, can. $20314^{\circ}$. Dla potwierdzenia cudu konieczni są 2 biegli. „Ad probationem miraculorum duo periti ex officio inducendi sunt initio discussionis; et si ambo fuerint concordes in reiiciendo miraculo, ad ulteriora ne procedatur". CIC 1917, can. $2118 \$ 1$. Por. T. Rozkrut, Walor opinii biegtego $w$ kanonicznym procesie matżeńskim, Tarnów 2002, s. 107.

5 „Documenta historica sive manu scripta, sive typis impressa, quibus postulator Servi Dei virtutes aut cultus eidem praestiti antiquitatem eiusque non interruptam continuationem probare intendit, inserantur in processum et cum ipso transmittantur ad Sacram Congregationem et a viris peritis examinentur". CIC 1917, can. $2036 \$ 1$.

6 „Si agatur de processu super miraculis, nominetur praeterea unus saltem peritus, qui sessionibus tribunalis adsit et iudicem rogare possit ut necessarias interrogationes testibus proponat ad maiorem assequendam verborum rerumque claritatem". CIC 1917, can. 2088 \$3. Por. T. Rozkrut, Walor opinii biegłego..., dz. cyt., s. 106. 
w Tarnowie w latach 1945-1983. Zrealizowanie tego celu, aczkolwiek nie w sposób wyczerpujący, nastąpi w drugiej części artykułu. Pierwsza część przedstawia natomiast normy prawne, które regulowały zasady funkcjonowania urzędu biegłego w sądach kościelnych w omawianym okresie.

\section{Normy regulujące działalność biegłych sądowych w ustawodawstwie kościelnym w latach 1917-1983}

Poniżej zostaną podane normy kanoniczne dotyczące biegłych sądowych zamieszczone w Kodeksie prawa kanonicznego z 1917 roku, a następnie normy wydane w tym zakresie w późniejszym okresie do promulgacji Kodeksu prawa kanonicznego z 1983 roku.

\section{I.I. Normy prawne odnośnie do biegłych sądowych w Kodeksie prawa kanonicznego z I9I7 roku ${ }^{7}$}

\section{I.I.I. SPOSÓB WYKONYWANIA URZĘDU PRZEZ BIEGŁYCH SĄDOWYCH}

Kodeks prawa kanonicznego z 1917 roku wymagał skorzystania ze współpracy z biegłymi, gdy wynikało z nakazu prawa lub z postanowienia sędziego, że jest konieczne dokonanie przez nich badania lub sporządzenie opinii (examen, votum) dla stwierdzenia jakiegoś faktu bądź poznania prawdziwej natury jakiejś rzeczy ${ }^{8}$.

7 Podział tematyki dotyczącej biegłych w CIC 1917 może być różnie przeprowadzony, np. Guidus Cocchi wyróżniał: „1. De peritorum necessitate. 2. De peritorum electione. 3. De peritorum munere. 4. De voto peritorum. 5. De peritiae vi. 6. De peritorum indemnitate". G. Cocchi, Commentarium in Codicem Iuris Canonici. Ad usum scholarum, Lib. 4, De processibus, ed. 3 recognita, Torino 1940, s. 275-282; por. F. Bączkowicz, Prawo kanoniczne, dz. cyt., s. 108-110, 243-246; S. Biskupski, Prawo małżeńskie Kościoła rzymskokatolickiego, dz. cyt., s. 265-275. Normy cic 1917 o biegłym sądowym można analizować także według kolejności numerycznej kanonów. Por. T. Rozkrut, Walor opinii biegłego..., dz. cyt., s. 107-110.

${ }^{8}$ „Peritorum opera utendum est quoties ex iuris vel iudicis praescripto eorum examen et votum requiritur ad factum aliquod comprobandum vel ad veram alicuius rei naturam dignoscendam”. ciC 1917, can. 1792. Por. L. Miguélez Domínguez, S. Alonso Morán, M. Cabreros de Anta, Código de derecho canónico..., dz. cyt., s. 670-671; I. Noval, Commentarium Codicis..., dz. cyt., s. 357; F. Bączkowicz, Prawo kanoniczne, dz. cyt., s. 108. 
Sędzia był kompetentny do wyboru lub wyznaczenia biegłych ${ }^{9}$. W sprawach czysto prywatnych mógł wyznaczyć biegłych na prośbę obydwu stron lub jednej z nich, ale za zgodą drugiej strony. Natomiast w sprawach, w których chodziło o dobro publiczne, wyznaczał biegłych po wysłuchaniu promotora sprawiedliwości lub obrońcy węzła małżeńskiego ${ }^{10}$.

Wybór jednego lub kilku biegłych był pozostawiony roztropnej ocenie sędziego w zależności od natury i trudności sprawy, chyba że samo prawo ustalało ich liczbę ${ }^{11}$.

Uwzględniając powyższe normy procesowe, rozróżniano biegłych przymusowych i biegłych dobrowolnych. W pierwszym przypadku biegły wykonywał swoje obowiązki na wezwanie sędziego z urzędu albo na mocy samego prawa. W drugim zaś strony prosiły o powołanie biegłego, a sędzia na to wyrażał zgodę. Ponadto biegli mogli być sądowi lub pozasądowi, w zależności od tego, czy pełnili swoje czynności na wezwanie sędziego w toku procesu sądowego czy poza nim².

Biegli mieli obowiązek sporządzić opinię, kierując się prawdą i sprawiedliwością. Za opinię fałszywą czy zatajenie prawdy groziła im kara przewidziana normami kodeksowymi, tak jak stronom za kłamstwo lub krzywoprzysięstwo ${ }^{13}$.

9 „Iudicis est peritos eligere vel designera”. CIC 1917, can. $1793 \$ 1$. Por. I. Noval, Commentarium Codicis..., dz. cyt., s. 357-358; F. X. Wernz, P. Vidal, Ius canonicum..., dz. cyt., Vol. vi, s. 449-450; L. Miguélez Domínguez, S. Alonso Morán, M. Cabreros de Anta, Código de derecho canónico..., dz. cyt., s. 671.

10 „Hanc designationem in causis mere privatis iudex facere potest rogatu utriusque partis vel etiam alterutrius, altera tamen consentiente; in causis vero bonum publicum respicientibus, audito promotore iustitiae aut vinculi defensore”. CIC 1917, can. $1793 \$ 2$. Por. L. Miguélez Domínguez, S. Alonso Morán, M. Cabreros de Anta, Código de derecho canónico..., dz. cyt., s. 671.

${ }^{11}$ „Prudenti iudicis arbitrio relinquitur unum pluresve peritos eligere pro causae natura et rei difficultate, nisi lex ipsa numerum peritorum praefiniat”. CIC 1917, can. $1793 \$ 3$. Por. F. X. Wernz, P. Vidal, Ius canonicum ..., dz. cyt., Vol. vi, s. 450; L. Miguélez Domínguez, S. Alonso Morán, M. Cabreros de Anta, Código de derecho canónico..., dz. cyt., s. 671.

${ }^{12}$ Por. S. Biskupski, Prawo małżeńskie Kościoła rzymskokatolickiego, dz. cyt., s. 266.

${ }^{13}$ „Peritorum est peritiam suam ad veritatis et iustitiae leges exigere, neque falsum affirmando neque verum occultando; in quo si deliquerint, puniantur ad normam can. 1743, $\$$ 3”. CIC 1917, can. 1794. Por. L. Miguélez Domínguez, S. Alonso Morán, M. Cabreros de Anta, Código de derecho canónico..., dz. cyt., s. 671. „Pars, quae respondere debet, si illegitime respondere recusaverit aut si postquam responderit mendax reperta fuerit, puniatur, ad tempus a iudice pro rerum adiunctis definiendum remotione ab actibus legitimis 
Na urząd biegłych mieli być wyznaczani ci, których zdatność została poświadczona świadectwem kompetentnego autorytetu ${ }^{14}$. Nie mogli być mianowani ci, którzy zgodnie z can. 1757 CIC 1917 byli wyłączeni z możliwości bycia świadkami ${ }^{15}$.

Biegli mogli być wykluczeni ze sprawy z tych samych przyczyn co świadkowie $^{16}$. Sędzia decydował dekretem, czy należy odrzucić czy dopuścić biegłego. W przypadku odrzucenia w jego miejsce sędzia wybierał innego ${ }^{17}$. Biegli składali przysięgę, że będą wiernie wykonywać swój urzą ${ }^{18}$. Strony mogły być obecne podczas składania przysięgi przez biegłego,

ecclesiasticis; et si ante responsionem iusiurandum de veritate dicenda praestiterit, laicus interdicto personali, clericus suspensione plectatur". cic 1917, can. $1743 \$ 3$. Por. F. Bączkowicz, Prawo kanoniczne, dz. cyt., s. 109.

${ }^{14}$ „Ad periti munus, ceteris paribus, deligantur, qui competentis magistratus auctoritate idonei fuerint comprobati”. CIC 1917, can. $1795 \$ 1$. Por. L. Miguélez Domínguez, S. Alonso Morán, M. Cabreros de Anta, Código de derecho canónico..., dz. cyt., s. 671; I. Noval, Commentarium Codicis..., dz. cyt., s. 358 .

${ }^{15}$ "Qui a testimonio ferendo exeluduntur ad normam can. 1757, ne ad peritorum quidem officium assumi possunt”. CIC 1917, can. $1795 \$$ 2. Por. L. Miguélez Domínguez, S. Alonso Morán, M. Cabreros de Anta, Código de derecho canónico..., dz. cyt., s. 671. „Ut non idonei repelluntur a testimonio ferendo impuberes et mente debiles. $\$ 2$. Ut suspecti: $1^{\circ}$ Excommunicati, periuri, infames, post sententiam declaratoriam vel condemnatoriam; $2^{\circ}$ Qui ita abiectis sunt moribus ut fide digni non habeantur; $3^{\circ}$ Publici gravesque partis inimici. \$3. Ut incapaces: $1^{\circ}$ Qui partes sunt in causa, aut partium vice funguntur, veluti tutor in causa pupilli, Superior aut administrator in causa suae communitatis aut piae causae, cuius nomine in iudicio consistit, iudex eiusve assistentes, advocatus aliique qui partibus in eadem causa assistunt vel astiterunt; $2^{\circ} \mathrm{Sa}$ cerdotes, quod attinet ad ea omnia quae ipsis ex confessione sacramentali innotuerunt, etsi a vinculo sigilli soluti sint; imo audita a quovis et quoquo modo occasione confessionis ne ut indicium quidem veritatis recipi possunt; $3^{\circ}$ Coniux in causa sui coniugis, consanguineus et affinis in causa consanguinei vel affinis, in quolibet gradu lineae rectae et in primo gradu collateralis, nisi agatur de causis quae ad statum civilem aut religiosum personae spectant, cuius notitia aliunde haberi nequeat, et bonum publicum exigat ut habeatur". CIC 1917, can. 1757.

${ }^{16}$ „Easdem ob causas quibus testes, possunt et periti recusari”. CIC 1917, can. $1796 \$ 1$. Por. L. Miguélez Domínguez, S. Alonso Morán, M. Cabreros de Anta, Código de derecho canónico..., dz. cyt., s. 671.

${ }_{17}$ „Iudex suo decreto edicat utrum sit admittenda recusatio, necne, et, recusatione admissa, in locum periti recusati alium sufficiat”. CIC 1917, can. $1796 \$ 2$. Por. L. Miguélez Domínguez, S. Alonso Morán, M. Cabreros de Anta, Código de derecho canónico..., dz. cyt., s. 671; I. Noval, Commentarium Codicis..., dz. cyt., s. 359.

${ }_{18}$ „Periti demandatum munus suscipere censentur praestatione iurisiurandi de munere fideliter implendo". CIC 1917, can. 1797 \$1. Por. L. Miguélez Domínguez, S. Alonso Morán, M. Cabreros de Anta, Código de derecho canónico..., dz. cyt., s. 671. 
jak i podczas wykonywania przez niego urzędu, chyba że czegoś innego wymagała natura sprawy lub przyzwoitość $\mathrm{z}$ nakazu prawa lub sędziego ${ }^{19}$. Gdyby biegli po złożeniu przysięgi nie wykonali w wyznaczonym czasie zleconego im przez sędziego zadania lub bez słusznej przyczyny odrzucili jego polecenie, byli zobowiązani do naprawienia wynikłych $\mathrm{z}$ tego powodu szkód ${ }^{20}$.

Sędzia, mając na uwadze, co strony podały w sprawie, określał dekretem punkty, wokół których powinna toczyć się praca biegłego ${ }^{21}$. Jeśliby sędzia uznał to za konieczne bądź stosowne, mógł wyznaczyć biegłemu czas, w którym miał zrealizować opinię. Sędzia mógł także prolongować ten termin po wcześniejszym wysłuchaniu stron ${ }^{22}$.

Biegli mogli przedstawić swoją opinię na piśmie lub ustnie wobec sędziego. W przypadku gdy opinia biegłego została przedstawiona ustnie, miała zostać natychmiast spisana przez notariusza i podpisana przez biegłego ${ }^{23}$.

Biegły, zwłaszcza ten, który sporządził pisemną opinię, mógł być wezwany przez sędziego w celu złożenia ewentualnych wyjaśnień ${ }^{24}$.

19 „Partes non solum interesse possunt iurisiurandi praestationi, sed etiam exsecutioni muneris perito demandati, nisi aliud rei natura vel honestas exigat aut lex vel iudex statuat". CIC 1917, can. $1797 \$ 2$. Por. L. Miguélez Domínguez, S. Alonso Morán, M. Cabreros de Anta, Código de derecho canónico..., dz. cyt., s. 672.

${ }^{20}$ „Post iusiurandum praestitum, si periti intra praefinitum tempus mandato non paruerint aut sine iusta causa exsecutionem defugiant, tenentur damnorum". CIC 1917, can. 1798. Por. L. Miguélez Domínguez, S. Alonso Morán, M. Cabreros de Anta, Código de derecho canónico..., dz. cyt., s. 672.

${ }^{21}$ „Iudex, attentis iis quae a litigantibus forte deducantur, omnia et singula capita decreto suo definiat circa quae periti opera versari debeat”. CIC 1917, can. $1799 \$$ 1. Por. L. Miguélez Domínguez, S. Alonso Morán, M. Cabreros de Anta, Código de derecho canónico..., dz. cyt., s. 672 .

${ }^{22}$ „Tempus intra quod examen perficiendum est et votum proferendum, si necessarium vel opportunum iudici videatur, potest ab ipso iudice praefiniri et etiam, auditis partibus, prorogari”. CIC 1917, can. $1799 \$$ 2. Por. L. Miguélez Domínguez, S. Alonso Morán, M. Cabreros de Anta, Código de derecho canónico..., dz. cyt., s. 672.

${ }^{23}$ „Periti votum suum vel in scriptis proferre possunt, vel oretenus coram iudice; sed si ore proferatur, statim in scriptis redigi debet a notario et a peritis subscribi”. CIC 1917, can. $1801 \$$ 1. Por. L. Miguélez Domínguez, S. Alonso Morán, M. Cabreros de Anta, Código de derecho canónico..., dz. cyt., s. 673.

${ }^{24}$ „Peritus autem, praescrtim si sententiam suam in scriptis protulerit, accersiri potest a iudice ut explicationes, quae ulterius necessariae videantur, suppeditet”. CIC 1917, can. 1801 \$ 2. Por. L. Miguélez Domínguez, S. Alonso Morán, M. Cabreros de Anta, Código 
Biegli byli zobowiązani wskazać z całą jasnością procedury i metody, które wykorzystali w wypełnianiu powierzonego im zadania, a przede wszystkim wyjaśnić, na jakich argumentach oparli swoją opinię ${ }^{25}$.

Każdy z biegłych sporządzał opinię oddzielnie od pozostałych. W przypadkach niezakazanych przez prawo sędzia mógł polecić biegłym sporządzenie jednej opinii, ale każdy z nich musiał ją podpisać. Gdy zaistniały rozbieżności w opiniach biegłych, należało je precyzyjnie odnotowaćć ${ }^{26}$. Kiedy biegli w danej opinii nie byli zgodni między sobą, sędzia mógł zażądać opinii jeszcze jednego biegłego (bieglejszego, peritioris) na temat sporządzonej opinii poprzednich biegłych lub wyznaczyć nowych ${ }^{27}$. Sędziemu przysługiwała ta sama kompetencja, gdyby biegli po ich wyborze okazali się podejrzani lub niezdolni czy nieodpowiedni do wykonania swojego urzędu ${ }^{28}$.

Sędzia miał za zadanie z dużą starannością rozważyć nie tylko zgodne wnioski biegłych, ale także wziąć pod uwagę wszystkie pozostałe okoliczności sprawy ${ }^{29}$.

de derecho canónico..., dz. cyt., s. 673; F. X. Wernz, P. Vidal, Ius canonicum..., dz. cyt., Vol. vi, s. $456-457$.

${ }^{25}$ „Periti debent indicare perspicue qua via et ratione processerint in explendo munere sibi demandato et quibus potissimum argumentis sententia ab ipsis prolata nitatur". CIC 1917, can. $1801 \$ 3$. Por. L. Miguélez Domínguez, S. Alonso Morán, M. Cabreros de Anta, Código de derecho canónico..., dz. cyt., s. 673; I. Noval, Commentarium Codicis..., dz. cyt., s. 361; H. Jone, Commentarium in Codicem Iuris Canonici, Vol. 3, Paderborn 1955, s. 170.

${ }^{26}$ „Periti suam quisque relationem a ceteris distinctam conficiant, nisi, lege non contradicente, iudex unam a singulis subscribendam fieri iubeat; quod si fiat, sententiarum discrimina, si qua fuerint, diligenter adnotentur". CIC 1917, can. 1802. Por. L. Miguélez Domínguez, S. Alonso Morán, M. Cabreros de Anta, Código de derecho canónico..., dz. cyt., s. 673 .

${ }^{27}$ „Si periti inter se discrepent, licet iudici aut peritioris suffragium super relatis a primis peritis exquirere aut novos de integro peritos adhibere”. CIC 1917, can. $1803 \$ 1$. Por. L. Miguélez Domínguez, S. Alonso Morán, M. Cabreros de Anta, Código de derecho canónico..., dz. cyt., s. 673; F. Bączkowicz, Prawo kanoniczne, dz. cyt., s. 110.

${ }_{28}$ „Eadem facultas iudici est quoties periti post electionem in suspicionem inciderint vel impares atque non idonei muneri perspecti fuerint”. CIC 1917, can. $1803 \$ 2$. Por. L. Miguélez Domínguez, S. Alonso Morán, M. Cabreros de Anta, Código de derecho canónico..., dz. cyt., s. 673 .

29 "Iudex non peritorum tantum conclusiones, etsi concordes, sed cetera quoque causae adiuncta attente perpendat”. cic 1917, can. $1804 \$ 1$. Por. L. Miguélez Domínguez, S. Alonso Morán, M. Cabreros de Anta, Código de derecho canónico..., dz. cyt., s. 674; I. Noval, Commentarium Codicis..., dz. cyt., s. 362; G. Cocchi, Commentarium in Codicem Iuris..., 
Po przedstawieniu motywów sentencji sędzia miał podać argumenty, które go skłoniły do przyjęcia lub odrzucenia wniosków biegłych ${ }^{30}$.

\section{I.I.2. WĄTPLIWOŚĆ CO DO AUTORSTWA PISMA}

Jeśli istniała wątpliwość, kto jest autorem danego pisma, sędzia na wniosek stron przedkładał biegłemu oprócz pisma podlegającego dyskusji także inne pisma, których autorstwo pozostawało pewne, aby przez porównanie pism było możliwe stwierdzenie autentyczności ${ }^{31}$.

Jeśli między stronami istniał brak zgodności, czy porównać między sobą to czy inne pismo, wówczas sam sędzia decydował, które z pism należy zestawić z pismami uznanymi przez stronę przy innej okazji za autentyczne albo pismami sporządzonymi przez autora pisma kontrowersyjnego pełniącego w danej chwili funkcję osoby publicznej, znajdującymi się w archiwum lub innym publicznym rejestrze dokumentów. Sędzia mógł także wybrać dla zestawienia pisma kontrowersyjne, które autor podpisał, a notariusz lub inna osoba publiczna potwierdzili, że zostały złożone w ich obecności ${ }^{32}$.

Jeśli zdaniem biegłego pisma wskazane przez strony i przez sędziego $\mathrm{w}$ celu porównania nie były wystarczające $\mathrm{w}$ dochodzeniu autentyczności pisma, a żył ten, któremu przypisywało się pismo kontrowersyjne, sędzia wzywał tę osobę na prośbę strony lub z urzędu, aby przed nim lub jego delegatem napisała ona własnoręcznie wszystko to, co jej zostanie

dz. cyt., s. 281; F. X. Wernz, P. Vidal, Ius canonicum..., dz. cyt., Vol. vi, s. 457-458; H. Jone, Commentarium in Codicem..., dz. cyt., s. 171.

30 "Cum reddit rationes decidendi, exprimere debet quibus motus argumentis peritorum conclusiones aut admiserit aut reiecerit”. CIC 1917, can. $1804 \$$ 2. Por. L. Miguélez Domínguez, S. Alonso Morán, M. Cabreros de Anta, Código de derecho canónico..., dz. cyt., s. 674; I. Noval, Commentarium Codicis..., dz. cyt., s. 362.

${ }^{31}$ „Si dubitetur quis scriptum aliquod exaraverit, iudex praeter scripturam quaestioni obnoxiam assignet peritis, proponentibus partibus, scripturas cum quibus illa comparari et conferri debeat". CIC 1917, can. $1800 \$ 1$. Por. L. Miguélez Domínguez, S. Alonso Morán, M. Cabreros de Anta, Código de derecho canónico..., dz. cyt., s. 672.

${ }^{32}$ „Si de scripturis, quae sint inter se comparandae, partes dissentiant, iudex seligat, comparationis gratia, eas, quas pars ipsa alias recognovit, aut quas qui accusatur auctor scripturae controversae, scripsit ut persona publica et in archivis aut alio publico tabulario custodiuntur; aut eius subscriptiones quas ex fide notarii vel personae publicae constet coram ipsis fuisse exaratas". CIC 1917, can. $1800 \$ 2$. Por. L. Miguélez Domínguez, S. Alonso Morán, M. Cabreros de Anta, Código de derecho canónico..., dz. cyt., s. 672 . 
podyktowane ${ }^{33}$. „W tym ostatnim przypadku należy podyktować takie wyrazy, jakie zachodzą w zakwestionowanym piśmie"34. Odmowa napisania podyktowanego pisma bez podania słusznej przyczyny uznana była za przyznanie się do autentyczności pisma kontrowersyjnego na niekorzyść odmawiającego ${ }^{35}$.

\section{I.I.3. WYNAGRODZENIE BIEGŁYCH SĄDOWYCH}

$\mathrm{Na}$ osobie sędziego spoczywało zadanie właściwego oszacowania wynagrodzenia za pracę biegłych i ustalenia ze słusznością należnych im honorariów i poniesionych przez nich kosztów związanych z wykonywaniem zadania, przy uwzględnieniu panującego $\mathrm{w}$ danym miejscu zwyczaju. Poszkodowanemu przysługiwało prawo rekursu w ciągu $10 \mathrm{dni}^{36}$.

${ }^{33}$ "Quod si scripturae a partibus et a iudice pro comparatione designatae, peritorum iudicio, investigationi non sufficiant, et is cui scriptura controversa tribuitur, in vivis sit, iudex ad instantiam partis aut etiam ex officio eum citet, ut manu propria coram iudice vel eius delegato scribat quidquid periti, iudex ipse, eiusve delegatus dictaturi sint". CIC 1917, can. $1800 \$ 3$. Por. L. Miguélez Domínguez, S. Alonso Morán, M. Cabreros de Anta, Código de derecho canónico..., dz. cyt., s. 672-673.

${ }^{34}$ T. Pawluk, Kanoniczne procesy..., dz. cyt., s. 284.

35 „Recusatio scribendi, non probata legitima recusationis causa, habetur ut confessio genuinitatis scripturae controversae in praeiudicium recusantis". CIC 1917, can. $1800 \$ 4$. Szerzej na temat badań grafognostycznych, które mają na celu zweryfikowanie autora pisma: T. Pawluk, Kanoniczne procesy..., dz. cyt., s. 284-285. Por. F. X. Wernz, P. Vidal, Ius canonicum..., dz. cyt., Vol. vi, s. 455-456; M. Lega, Commentarius in iudicia ecclesiastica..., dz. cyt., s. 758-762; M. Conte a Coronata, Compendium iuris canonici, dz. cyt., s. 276; L. Miguélez Domínguez, S. Alonso Morán, M. Cabreros de Anta, Código de derecho canónico..., dz. cyt., s. 673 .

${ }^{36}$ „Peritorum expensas et honoraria iudex, receptam uniuscuiusque loci consuetudinem prae oculis habens, ex bono et aequo taxare debet, salvo iure recursus ad normam can. 1913, \$1”. CIC 1917, can. 1805. Por. L. Miguélez Domínguez, S. Alonso Morán, M. Cabreros de Anta, Código de derecho canónico..., dz. cyt., s. 674. „A pronuntiatione circa expensas non datur distincta appellatio; sed pars quae se gravatam putat, oppositionem intra decem dies facere potest coram eodem iudice: qui de hac re cognoscere denuo poterit, et taxationem emendare ac moderari”. CIC 1917, can. $1913 \$$ 1. Por. F. Bączkowicz, Prawo kanoniczne, dz. cyt., s. 110. 


\section{I.I.4. NORMY O POWOŁYWANIU BIEGŁYCH W SPRAWACH MAŁŻEŃSKICH} (CAN. I978-I982 CIC I9I7)

Kodeks pio-benedyktyński w can. 1977 stwierdzał, że przy wyborze biegłych należało uwzględniać normy zawarte w can. 1792-1805 i 1978-1982 ${ }^{37}$, a więc normy generalne o działalności biegłych sądowych w powiązaniu z normami szczegółowymi o ich zadaniach w procesach małżeńskich. Nie dopuszczało się do wykonywania zadania biegłych znających prywatnie małżonków w tym aspekcie, na którym opierała się ich prośba o stwierdzenie nieważności małżeństwa lub jego niedopełnienia. Ci biegli mogli jedynie pełnić funkcję świadków tych osób ${ }^{38}$.

W sprawach impotencji małżonka lub niedopełnienia małżeństwa należało za pośrednictwem biegłych dokonać kontroli ciał obydwu małżonków lub ciała jednego z nich, chyba że po rozważeniu okoliczności okazało się to całkowicie nieprzydatne ${ }^{39}$.

W celu rozpoznania mężczyzny powinno być wyznaczonych z urzędu 2 biegłych lekarzy ${ }^{40}$, a w przypadku kobiety należało wyznaczyć z urzędu 2 dyplomowane położne, chyba że kobieta wolałaby być badana przez 2 lekarzy, którzy musieliby być tak samo wyznaczeni z urzędu, lub ordynariusz uznałby to ostatnie za konieczne ${ }^{41}$.

${ }^{37}$ „In peritis eligendis, praeter normas in can. 1792-1805 datas, serventur praescripta canonum qui sequuntur". CIC 1917, can. 1977. Por. L. Miguélez Domínguez, S. Alonso Morán, M. Cabreros de Anta, Código de derecho canónico..., dz. cyt., s. 732.

${ }_{38}$ „Ad periti munus ne admittantur qui coniuges privatim inspexerint circa factum cui innititur petitio declarationis nullitatis vel inconsummationis; licet tamen hos tanquam testes inducere". CIC 1917, can. 1978. Por. L. Miguélez Domínguez, S. Alonso Morán, M. Cabreros de Anta, Código de derecho canónico..., dz. cyt., s. 732.

39 „In causis impotentiae aut inconsummationis requiritur inspectio corporis utriusque vel alterutrius coniugis per peritos facienda, nisi ex adiunctis inutilis evidenter appareat". CIC 1917, can. 1976. Por. L. Miguélez Domínguez, S. Alonso Morán, M. Cabreros de Anta, Código de derecho canónico..., dz. cyt., s. 732.

40 "Ad inspiciendum virum, duo periti medici ex officio deputari debent". CIC 1917, can. 1979 \$ 1. Por. L. Miguélez Domínguez, S. Alonso Morán, M. Cabreros de Anta, Código de derecho canónico..., dz. cyt., s. 732.

${ }^{41}$ „Ad mulierem vero inspiciendam duae obstetrices, quae legitimum peritiae testimonium habeant, ex officio designentur; nisi maluerit mulier a duobus medicis ex officio pariter designandis inspici vel id Ordinarius necessarium habuerit”. CIC 1917, can. $1979 \$ 2$. Por. L. Miguélez Domínguez, S. Alonso Morán, M. Cabreros de Anta, Código de derecho canónico..., dz. cyt., s. 732. 
Badanie lekarskie ciała kobiety należało przeprowadzać z całkowitym zachowaniem wszystkich zasad przyzwoitości chrześcijańskiej i zawsze w obecności prawej (budzącej zaufanie) matrony, która była wyznaczana z urzędu ${ }^{42}$. Każdy z biegłych czy z położnych przeprowadzał oddzielnie badanie kobiety ${ }^{43}$. Po przeprowadzonym badaniu każdy z lekarzy czy z położnych sporządzał oświadczenie (sprawozdanie) z badania, które oddawał sędziemu w wyznaczonym przez niego terminie ${ }^{44}$.

Gdyby sędziemu wydawało się to stosowne, miał prawo, aby oświadczenia dokonane przez położne skierować do biegłego lekarza w celu ich weryfikacji ${ }^{45}$.

Kiedy biegli i położne sporządzili sprawozdania $z$ badania lekarskiego, sędzia miał przesłuchać ich osobno, łącznie z matroną. Przesłuchanie miało być przeprowadzone według pytań (zagadnień) zredagowanych uprzednio przez obrońcę węzła małżeńskiego. Przesłuchiwani odpowiadali na nie po złożeniu przysięgi ${ }^{46}$.

O opinię biegłych miało się także prosić w przypadkach braku zgody z powodu amencji (choroby psychicznej). Biegli poddawali chorego badaniu lekarskiemu, jeśli dany przypadek tego wymagał, oraz zapoznawali się uważnie $\mathrm{z}$ aktami (dokumentacją) osoby uważanej za dotkniętą amencją. Ponadto w rozpatrywanym przypadku powinno się wysłuchać jako świadków tych biegłych, którzy wcześniej badali chorego ${ }^{47}$.

42 "Corporalis mulieris inspectio fieri debet, servatis plene christianae modestiae regulis et adstante semper honesta matrona ex officio designanda”. CIC 1917, can. $1979 \$ 3$. Por. L. Miguélez Domínguez, S. Alonso Morán, M. Cabreros de Anta, Código de derecho canónico..., dz. cyt., s. 732; G. Cocchi, Commentarium in Codicem Iuris..., dz. cyt., s. 484.

43 "Mulieris inspectionem obstetrices vel periti, seorsum singuli, exsequi debent". CIC 1917, can. 1980 \$ 1. Por. L. Miguélez Domínguez, S. Alonso Morán, M. Cabreros de Anta, Código de derecho canónico..., dz. cyt., s. 732.

44 „Singuli medici vel obstetrices singulas relationes conficiant, intra terminum a iudice praefinitum tradendas”. CIC 1917, can. $1980 \$$ 2. Por. L. Miguélez Domínguez, S. Alonso Morán, M. Cabreros de Anta, Código de derecho canónico..., dz. cyt., s. 732.

45 „Potest iudex relationes ab obstetricibus confectas examini alicuius periti medici subiicere, si id opportunum existimaverit”. CIC 1917, can. 1980 \$3. Por. L. Miguélez Domínguez, S. Alonso Morán, M. Cabreros de Anta, Código de derecho canónico..., dz. cyt., s. 732.

${ }^{46}$ „Peracta relatione, periti, obstetrices ac matrona, seorsum singuli, a iudice interrogentur, secundum articulos a vinculi defensore antea concinnatos quibus ipsi, praestito iuramento, respondeant". CiC 1917, can. 1981. Por. L. Miguélez Domínguez, S. Alonso Morán, M. Cabreros de Anta, Código de derecho canónico..., dz. cyt., s. 732-733.

47 „Etiam in causis defectus consensus ob amentiam, requiratur suliragium peritorum, qui infirmum, si casus ferat, eiusve acta quae amentiae suspicionem ingerunt, examinent 


\section{I.2. Dokumenty prawne o biegłych sądowych opublikowane w okresie między Kodeksem prawa kanonicznego z I9I7 roku a Kodeksem prawa kanonicznego z I983 roku}

W okresie między promulgacją Kodeksu pio-benedyktyńskiego w 1917 roku a wejściem w życie Kodeku prawa kanonicznego z 1983 roku zostały opublikowane następujące dokumenty prawne, które mówiły o zastosowaniu opinii biegłych jako środka dowodowego ${ }^{48}$ :

1. dekret Catholica doctrina (1923) ${ }^{49}$;

2. Normae observandae in processibus super matrimonio rato et non consummato ad praecavendam dolosam personarum substitutionem (1929) ${ }^{50}$;

3. motu proprio Piusa xi Già da qualche tempo (1930) ${ }^{51}$;

4. Regulae servandae in processibus super nullitate sacrae ordinationis $(1931)^{52}$;

5. Normae S. Romanae Rotae Tribunalis (1934) ${ }^{53}$;

6.instrukcja Provida Mater Ecclesia (1936) ${ }^{54}$;

7. normy kanonizacyjne na temat spraw historycznych (1939) ${ }^{55}$;

secundum artis praecepta; insuper uti testes audiri debent periti qui infirmum antea visitaverint”. CIC 1917, can. 1982. Por. L. Miguélez Domínguez, S. Alonso Morán, M. Cabreros de Anta, Código de derecho canónico..., dz. cyt., s. 733.

${ }^{48}$ Tomasz Rozkrut wymienia je w porządku chronologicznym; por. T. Rozkrut, Walor opinii biegłego..., dz. cyt., s. 114 .

49 Sacra Congregatio de Disciplina Sacramentorum, De processibus in causis dispensationis super matrimonio rato et non consummato, „Acta Apostolicae Sedis” [dalej: AAs] 15 (1923), s. 389-436.

50 Sacra Congregatio de Disciplina Sacramentorum, Normae observandae in processibus super matrimonio rato et non consummato ad praecavendam dolosam personarum substitutionem, AAS 21 (1929), s. 490-493.

${ }^{51}$ Pius XI, m.p. Instituitur "Sectio Historica» penes Sacrorum Rituum Congregationem Già da qualche tempo, AAS 22 (1930), s. 87-88.

${ }^{52}$ Sacra Congregatio de Sacramentis, Regulae servandae in processibus super nullitate sacrae ordinationis vel onerum sacris ordinibus inhaerentium a Sacra Congregatione de disciplina sacramentorum editae, AAS 23 (1931), s. 457-492.

53 Sacra Romana Rota, Normae S. Romanae Rotae Tribunalis, AAS 26 (1934), s. 449-491.

${ }^{54}$ Sacra Congregatio de Disciplina Sacramentorum, Instructio servanda a tribunalibus dioecesanis in pertractandis causis de nullitate matrimoniorum Provida Mater Ecclesia, AAS 28 (1936), s. 313-372 [dalej: PME].

55 Sacra Congregatio Rituum, Normae Servandae in construendis processibus ordinariis super causis historicis, AAS 31 (1939), s. 174-175. 
8. dekret Qua singulari na temat impotencji i niedopełnienia (1942) ${ }^{56}$;

9. motu proprio Piusa XII Sollicitudinem Nostram (1950) ${ }^{57}$;

10. Normae speciales Najwyższego Trybunału Sygnatury Apostolskiej $(1968)^{58}$;

11. Nova agendi ratio in doctrinarum examine Kongregacji Nauki Wiary $(1971)^{59}$;

12. instrukcja Dispensationis matrimonii $(1972)^{60}$.

I.2.I. NORMY PRAWNE ODNOŚNIE DO BIEGEYCH SĄDOWYCH W ART. I39-I54 instrukcu PRovida Mater ECCLESIA Z I936 ROKU

Ze względu na szczególne znaczenie instrukcji Provida Mater Ecclesia $\mathrm{w}$ procesach małżeńskich wymaga ona osobnego omówienia.

Instrukcja kanoniczna Provida Mater Ecclesia opublikowana została przez Świętą Kongregację do spraw Sakramentów 15 sierpnia 1936 roku Bazowała na normach Kodeksu prawa kanonicznego z 1917 roku i prz stosowywała je do procesu małżeńskiego, stanowiąc pewnego rodzaju suplement ${ }^{61}$. Możemy zauważyć analogię do panującej aktualnie relacji, jaka istnieje między Kodeksem prawa kanonicznego z 1983 roku i instrukcją Dignitas connubii wydaną 25 stycznia 2005 roku przez $\mathrm{Pa}-$ pieską Radę do spraw Tekstów Prawnych ${ }^{62}$.

${ }^{56}$ Suprema Sacra Congregatio Sancti Officii, decretum „Qua singulari” de quibusdam cautelis adhibendis in causis matrimonialibus impotentiae et inconsummationis, AAS 34 (1942), s. 200-202.

${ }^{57}$ Pius XII, m.p. De iudiciis pro Ecclesia Orientali „Sollicitudinem Nostram”, AAS 42 (1950), s. 5-120.

${ }^{5}$ Secretaria Status, Normae speciales in Supremo Tribunali Signaturae Apostolicae ad experimentum servandae, „Enchiridion Vaticanum” [dalej: Ev] 8 (1984), s. 522-587.

59 Sacra Congregatio pro Doctrina Fidei, Nova agendi ratio in doctrinarum examine, AAS 63 (1971), s. 234-236.

${ }^{60}$ Sacra Congregatio de Disciplina Sacramentorum, Instructio Dispensationis matrimonii. Instructio de quibusdam emendationibus circa normas in processu super matrimonio rato et non consummato servandas, AAs 64 (1972), s. 244-252.

${ }^{61}$ Por. T. Rozkrut, Walor opinii biegłego..., dz. cyt., s. 116, 119.

${ }^{62}$ Pontificium Consilium de Legum Textibus, Instructio servanda a Tribunalibus dioecesanis et interdioecesanis in pertractandis causis nullitatis matriomonii, "Communicationes" 37 (2005), s. 11-92. 
Według instrukcji Provida Mater Ecclesia należało wymagać opinii biegłych $\mathrm{w}$ sprawach $\mathrm{z}$ tytułu impotencji i braku zgody ze względu na chorobę umysłową ${ }^{63}$. W innych przypadkach opinia biegłych była wymagana, gdy należało osądzić coś, do czego musiało się posiadać szczególną znajomość rzeczy, np. stwierdzić autentyczność danego pisma (por. can. 1972 CIC 1917) ${ }^{64}$.

O konieczności ekspertyzy decydował sędzia instruktor na prośbę jednej ze stron lub z urzędu, zawsze po wysłuchaniu zdania obrońcy węzła małżeńskiego. W przypadku gdy strony nie zgodziły się na ekspertyzę, sprawa była przedstawiana kolegium przez sędziego instruktora ${ }^{65}$.

O wyborze biegłych i ich liczbie, z wyjątkiem przypadków określonych przez prawo (takich jak np. sprawa $z$ tytułu impotencji), decydował przewodniczący kolegium po wysłuchaniu zdania obrońcy węzła małżeńskiego ${ }^{66}$.

Na urząd biegłego mieli być wybierani jedynie ci, którzy otrzymali odpowiedni dyplom (świadectwo) od kompetentnych władz, posiadali znaczne doświadczenie w swoim zawodzie i cieszyli się opinią osób religijnych i uczciwych ${ }^{67}$. Jak twierdzi Stefan Biskupski:

${ }^{63}$ „In causis impotentiae et defectus consensus ob amentiam requirendum est suffragium peritorum (cfr. cann. 1976-1982)”. PME, art. 139. „Nie chodzi tu o konieczność bezwzględną. Wyrok będzie ważny, jeżeli sąd zdobędzie pewność moralną w oparciu o inne środki dowodowe. Zwyczajnie jednak w tych sprawach trudno wyrobić moralną pewność bez uciekania się do opinii biegłych". T. Pawluk, Kanoniczne procesy..., dz. cyt., s. 280. Por. F. Bączkowicz, Prawo kanoniczne, dz. cyt., s. 243; S. Biskupski, Prawo małżeńskie Kościoła rzymskokatolickiego, dz. cyt., s. 267-268.

${ }^{64}$ „In aliis causis peritorum sententia est exquirenda, quoties iudicium est faciendum, quod peculiarem in aliqua arte requirat peritiam: e.g. si de cuius scripti authenticitate inquirendum sit (cfr. can. 1792)”. PME, art. $140 \$ 1$.

${ }^{65}$ "An, in casu de quo in $\$ 1$, peritiae locus esse debeat, instructor decernet sive una ex partibus postulante sive ex officio, audito in quocumque casu vinculi defensore. Partibus dissentientibus, instructorem collegio referat". PME, art. $140 \$ 2$. Por. F. Bączkowicz, Prawo kanoniczne, dz. cyt., s. 243; S. Biskupski, Prawo małżeńskie Kościoła rzymskokatolickiego, dz. cyt., s. 267.

66 „Periti designandi sunt, audito vinculi defensore, a praeside, cuius est eorum numerum praefinire (cfr. can. 1793); salvo praescripto art. 150". PME, art. 141.

${ }^{67}$ "Ad periti munus deligantur qui non tantum idoneitatis testimonium a competenti magistratu obtinuerunt, sed etiam qui artis suae experientia sint insignes et religionis atque honestatis laude commendati”. PME, art. $142 \$ 1$. 
W dziedzinie lecznictwa musi to być zatem dyplomowany lekarz, o ile to możliwe ze stopniem naukowym doktora medycyny i wybranym kierunkiem specjalistycznym, np. lekarz psychiatra, lekarz ginekolog itp.; ponadto musi posiadać kilkuletnią praktykę kliniczną ${ }^{68}$.

Kto był wykluczony od składania zeznań w charakterze świadka, nie mógł być powołany na urząd biegłego. Jest to powtórzenie przez instrukcję Provida Mater Ecclesia normy zawartej w can. $1795 \$ 2$ CIC $1917^{69}$. Aby uniknąć podejrzeń o stronniczość, z urzędu biegłego wyłączeni zostali ci, których łączyły ścisłe związki z którąś ze stron ${ }^{70}$, „np. pokrewieństwa lub powinowactwa $\mathrm{w}$ jakimkolwiek stopniu linii prostej albo w pierwszym stopniu linii bocznej, przysposobienia (adopcji), kurateli, zażyłej przyjaźni itp."’1.

Z urzędu biegłego wyłączeni byli także ci, którzy badali prywatnie którąś ze stron w sprawach z tytułu impotencji i choroby umysłowej. Mogli być oni wezwani jedynie jako świadkowie w przypadku spraw dotyczących impotencji strony, a musieli być wezwani w takim charakterze w wypadku stwierdzenia choroby umysłowej strony ${ }^{72}$.

Gdyby się zdarzyło, że biegli przed wykonaniem ekspertyzy byliby podejrzani lub niezdolni do podjęcia swojego zadania, mieli być zastąpieni kimś innym przez przewodniczącego ${ }^{73}$.

Jedna ze stron lub obydwie strony mogły dokonać ekscepcji biegłych, gdyby byli oni podejrzani o stronniczość. Przewodniczący w każdym z tych przypadków musiał orzec dekretem, czy zarzut należy przyjąć czy

${ }^{68}$ S. Biskupski, Prawo małżeńskie Kościoła rzymskokatolickiego, dz. cyt., s. 267.

${ }^{69}$ Patrz przypis 15.

$7^{\circ}$ „Excluduntur quoque a periti munere qui quemlibet cum alterutra parte necessitudinis nexum habeant”. PME, art. $142 \$ 3$. Por. S. Biskupski, Prawo matżeńskie Kościoła rzymskokatolickiego, dz. cyt., s. 267-268.

${ }^{71}$ F. Bączkowicz, Prawo kanoniczne, dz. cyt., s. 243-244.

72 „In causis impotentiae vel amentiae excluduntur quoque a periti munere qui coniugem privatim inspexerunt; hi autem in casu impontentiae possunt (cfr. can. 1978), in casu amentiae debent (cfr. can. 1982), induci uti testes". PME, art. 143. Por. can. 1978 i 1982 CIC 1917. Por. S. Biskupski, Prawo małżeńskie Kościoła rzymskokatolickiego, dz. cyt., s. 268.

${ }^{73}$ „Si periti ante peritiam exaratam, aut suspecti evaserint, aut eos muneri obeundo impares esse compertum fuerit, a praeside substituendi erunt, ad normam art. 141". PME, art. 144 . 
go odrzucić. Gdy zarzut okazał się słuszny, w miejsce usuniętego biegłego miał zostać wybrany inny ${ }^{74}$.

Biegli byli zobowiązani wobec przewodniczącego, po wezwaniu stron i obrońcy węzła małżeńskiego, do złożenia przysięgi o wiernym spełnieniu swojego zadania i zachowaniu tajemnicy ${ }^{75}$.

Po wysłuchaniu stron i obrońcy węzła małżeńskiego instruktor wydawał dekret - wyszczególniał w nim w punktach zagadnienia, na które biegły miał udzielić odpowiedzi, np. „czy choroba umysłowa jest stała czy przejściowa, czy dopuszcza jasne okresy; czy niemoc płciowa jest bezwzględna czy tylko względna; czy instrumentalna czy też funkcjonalna; czy uprzednia czy też następcza; trwała czy też uleczalna bez większego niebezpieczeństwa dla życia"76.

Instruktor miał przekazać biegłym z akt sprawy wszystko, co uznał za konieczne lub słuszne, aby mogli wydać jak najbardziej rzetelną opinię?.

Strony miały prawo podać zagadnienia, które biegli powinni uwzględniać. Instruktor jednak decydował, czy należy je biegłym przedstawić lub je odrzucić, czego mógł dokonać z powodu słusznej przyczyny i po wysłuchaniu obrońcy węzła małżeńskiego ${ }^{78}$.

${ }^{74}$ „Periti possunt ab utraque vel ab alterutra parte recusari; si de partium studio sint suspecti (cfr. can. $1796 \$ 1$ ). In quolibet casu praeses suo decreto edicat utrum sit admittenda recusatio necne et, recusatione admissa, in locum periti recusati alium sufficiat ad normam art. 141 (cfr. can. $1796 \$ 2$ )”. PME, art. 145. Por. S. Biskupski, Prawo małżeńskie Kościoła rzymskokatolickiego, dz. cyt., s. 268.

75 „Periti iusiurandum de officio fideliter adimplendo et de secreto servando praestare debent coram praeside, citatis partibus et vinculi defensore". PME, art. 146.

${ }^{76}$ "Instructor decreto suo definiat, auditis partibus et defensore vinculi, omnia et singula capita circa quae peritorum opera versari debet (cfr. can. $1799 \$ 1$ ): ut puta, utrum amentia sit habitualis, an fuerit transitoria et an lucida admiserit intervalla; utrum impotentia sit absoluta an tantum relativa, utrum instrumentalis an functionalis, utrum antecedens an subsequens matrimonium, utrum perpetua an sanar bilis sine gravi vitae periculo". PME, art. 147 \$1. Por. S. Biskupski, Prawo małżeńskie Kościoła rzymskokatolickiego, dz. cyt., s. $263,269$.

77 „Peritis, ut iudicium suum recte facere possint, omnia causae acta, quae instructori necessaria aut opportuna videantur, remittenda sunt". PME, art. $147 \$ 2$.

${ }^{78}$ „Partibus fas est quaestiones proponere, de quibus, nisi instructor; audito vinculi defensore, ex iusta causa eas reiiciendas censuerit, periti, in peritia conficienda, rationem habere debent". PME, art. $147 \$ 3$. 
Instruktor miał wyznaczyć biegłym okres, w którym mieli oni przeprowadzić badanie i złożyć opinię. Termin ten mógł zostać przez niego prolongowany z powodu słusznej przyczyny i po wysłuchaniu stron ${ }^{79}$. Artykuł 148 instrukcji PME jest pewnym powtórzeniem can. 1802 CIC 1917. Biegli mieli badać stronę pojedynczo i oddzielnie, bez ujawniania sobie nawzajem wyników badania. W opinii należało wyraźnie zaznaczyć, jakie zostały zastosowane metoda i sposób postępowania oraz na jakich dowodach opierały się wnioski końcowe. Opinie miały zostać wyrażone na piśmie i własnoręcznie podpisane przez każdego biegłego ${ }^{80}$. Jedynie z wyjątkowej przyczyny przewodniczący mógł zdecydować, aby badanie biegłych przebiegało kolegialnie. Jeśli w tym przypadku pojawiły się wśród nich różnice zdań, miały zostać one wyszczególnione $\mathrm{w}$ sprawozdaniu z podaniem argumentów przemawiających za danym stanowiskiem $^{81}$.

W sprawie badania autentyczności jakiegoś pisma instrukcja PME podtrzymuje w mocy postanowienia can. $1800 \mathrm{CIC} 1917^{82}$.

W przypadku prowadzenia spraw o stwierdzenie nieważności małżeństwa z tytułu impotencji instrukcja Provida Mater Ecclesia nakazywała, aby do zbadania mężczyzny byli wyznaczeni 2 lekarze, którzy mieli być pouczeni, że podczas badania powinni kierować się jedynie uczciwymi środkami ${ }^{83}$. Jeżeli natomiast sprawa dotyczyła przeprowadzenia badania kobiety, należało wyznaczyć 2 osoby płci żeńskiej ze stopniem naukowym

79 „Praefigatur quoque ab instructore tempus intra quod examen est perficiendum et votum proferendum: quod tempus ab ipso instructore ex rationabili causa, partibus auditis, prorogari potest (cfr. can. $1799 \$ 2$ )". PME, art. $147 \$ 4$.

80 „Periti examen singillatim et seorsim exsequi debent; alter alteri examinis exitum ne pandat; votum suum in scriptis uterque proferat; in relatione, propria manu subscripta, perspicue quisque indicet qua via et ratione in explendo munere sibi demandato processerit, et quibus potissimis argumentis conclusiones prolatae nitantur (cfr. can. 1802)". PME, art. $148 \$ 1$. Por. S. Biskupski, Prawo małżeńskie Kościoła rzymskokatolickiego, dz. cyt., s. 269-270. Wzór sprawozdania biegłego lekarza w języku łacińskim za Reném Bassibeyem w: S. Biskupski, Prawo małżeńskie Kościoła rzymskokatolickiego, dz. cyt., s. 270-271.

${ }^{81}$ „Praeses decernere poterit, ex peculiari ratione, ut examen a peritis collegialiter exsequatur. Quo in casu peritorum discrimina, si quae adsint, in relatione, datis rationibus, adnotentur". PME, art. $148 \$ 2$.

${ }^{82}$ „Si agatur de cuius scripti authenticitate investiganda, standum est dispositioni can. 180o". PME, art. 149. Patrz przypisy 31-35.

${ }_{33}$ „In causis impotentiae: ad inspiciendum virum duo medici deputentur, qui monendi sunt ut honestis tantum mediis utantur ad impotentiam cognoscendam". PME, art. 150 n. 1. 
doktora medycyny, jeśli to było możliwe, i posiadające doświadczenie w swoim zawodzie. Istniała także druga możliwość zbadania kobiety, ale jedynie za jej zgodą i z postanowienia kolegium sędziowskiego. Mianowicie badania kobiety mogli dokonać 2 lekarze (mężczyźni) lub przynajmniej 2 prawdziwie biegłe akuszerki z dużym doświadczeniem. Przy przeprowadzaniu badania ciała kobiety zawsze należało w pełni kierować się zasadami chrześcijańskiej skromności; wymagana była też obecność wyznaczonej z urzędu poważanej matrony ${ }^{84}$.

Do spraw związanych z chorobą umysłową należało wyznaczyć według omawianej instrukcji 1 lekarza, a gdy stan chorobowy był poważny - 2 lekarzy, specjalistów w naukach psychiatrycznych. Instrukcja przestrzegała, aby nie powoływać tych lekarzy, którzy nie uwzględniali zdrowej nauki katolickiej ${ }^{85}$. Biegły (lekarz psychiatra), po złożeniu przysięgi, że sumiennie wypełni zlecone zadanie, badał chorego uznanymi przez naukę metodami, diagnozował rodzaj choroby, okres jej trwania, „przebieg, objawy, wpływ na władze poznawcze i wolę, trwałość, możliwość jasnych okresów itp." ${ }^{.86}$.

Obowiązkiem instruktora było wezwać biegłych, po uprzednim przekazaniu przez nich sprawozdania $z$ wyznaczonej sprawy, aby każdy $z$ nich $z$ osobna swoje wnioski jeszcze raz przejrzał i potwierdził je przez złożenie przysięgi oraz udzielił odpowiedzi na pytania obrońcy węzła małżeńskiego ${ }^{87} \mathrm{i}$ ewentualnie na pytania podane przez promotora

${ }^{84},[\ldots]$ ad inspiciendam mulierem deputentur duae mulieres, si adsint, quae in arte medica laurea doctorali et experientia sint praeditae, vel, ex mulieris consensu aut ex decisione collegii, duo medici, sin minus duae obstetrices vere peritae. Corporalis mulieris inspectio fieri debet regulis christianae modestiae plene servatis et adstante semper honesta matrona ex officio designanda (cfr. can. 1979)". PME, art. 150 n. 2. Por. S. Biskupski, Prawo małżeńskie Kościoła rzymskokatolickiego, dz. cyt., s. 272; T. Pawluk, Kanoniczne procesy..., dz. cyt., s. 349.

${ }^{85}$ „In causis amentiae unus vel, pro casus gravitate, duo medici deputentur, qui in scientia psychiatrica peculiariter sint versati; cauto tamen ut excludantur qui sanam (catholicam) doctrinam hac in re non profiteantur". PME, art. 151.

${ }^{86}$ S. Biskupski, Prawo małżeńskie Kościoła rzymskokatolickiego, dz. cyt., s. 274.

${ }^{87}$ „Exhibitis relationibus, instructoris erit peritos vocare, ut singillatim suas conclusiones recognoscant et iuramento confirment et quaestionibus a vinculi defensore opportune concinnatis respondeant”. PME, art. 152. Przykład pytań ułożonych przez obrońcę węzła małżeńskiego i zadawanych biegłemu przez sędziego - por. S. Biskupski, Prawo małżeńskie Kościoła rzymskokatolickiego, dz. cyt., s. 271. 
sprawiedliwości ${ }^{88}$. Gdyby zdarzyło się, że opinie biegłych są rozbieżne, przewodniczący trybunału mógł wyznaczyć innego biegłego, tzw. bieglejszego (peritiorem), aby wyraził swoją opinię ${ }^{89}$.

Przy wydawaniu wyroku trybunał nie był zobligowany postępować za orzeczeniem biegłych, nawet gdyby ich zdania były zgodne, ale miał starannie rozważyć także inne okoliczności sprawy ${ }^{90}$. Trybunał, przedstawiając w wyroku motywy sprawy, musiał jednak ustosunkować się do opinii biegłych i wyrazić, jakimi kierował się racjami za przyjęciem lub odrzuceniem ich wniosków ${ }^{91}$.

\section{I.2.2. NORMY O BIEGŁYCH SĄDOWYCH ZAWARTE W DOKUMENTACH KOŚCIELNYCH} W OKRESIE MIĘDZY CIC I9I7 A KPK I983 Z WYJąTKIEM INSTRUKCJI PROVIDA MATER ECCLESIA

Dekret Catholica doctrina wydany przez Kongregację do spraw Sakramentów 7 maja 1923 roku stwierdzał, że biegli mieli obowiązek złożenia przysięgi „dla potwierdzenia rzetelności powierzonego im zadania i prawdziwości wydanej opinii”"92.

Normae observandae in processibus super matrimonio rato et non consummato ad praecavendam dolosam personarum substitutionem Kongregacji do spraw Sakramentów z 27 marca 1929 roku stwierdzały, że „w przypadku występowania w procesie biegłego należy zachować specyficzne środki

${ }^{88}$ Por. F. Bączkowicz, Prawo kanoniczne, dz. cyt., s. 246.

${ }^{89}$ „Si periti inter se discrepent, praeses alium, quem vocant peritiorem, designare poterit ad normam art. 141, qui suum votum proferat atque confirmet ad normam art. 148 et 152". PME, art. 153. Por. S. Biskupski, Prawo małżeńskie Kościoła rzymskokatolickiego, dz. cyt., s. 271.

${ }_{90}$ „Tribunal non tenetur sequi peritorum iudicium, etsi eorum conclusiones sint concordes, sed cetera quoque causae adiuncta attente perpendat (cfr. can. $1804 \$ 1$ )”. PME, art. $154 \S 1$.

${ }_{91}$ „Tribunal debet in rationibus decidendi exprimere, quibus motum argumentis peritorum conclusiones vel admiserit vel reiecerit (cfr. can. $1804 \$ 2$ )”. PME, art. $154 \$ 2$. Por. S. Biskupski, Prawo małżeńskie Kościoła rzymskokatolickiego, dz. cyt., s. 275.

${ }_{92}$ T. Rozkrut, Walor opinii biegłego..., dz. cyt., s. 114-115. „Hoc proinde est solemniter praemonendum a iudice antequam iusiurandum praestetur, et animo reputandum ab omnibus qui in his causis partem habent, praecipue eo momento quo a partibus, a testibus, a peritis, respective, redduntur iuratae responsiones, attestationes, relationes". De processibus in causis dispensationis super matrimonio rato et non consummato, s. 390. 
i normy ostrożności. Biegli mają charakteryzować się odpowiednimi kwalifikacjami, swoje zadanie mają wykonywać według przepisanych reguł"93. Dokumentem Stolicy Świętej, który także mówił o udziale biegłych w sprawach super matrimonio rato et non consummato, była instrukcja Dispensationis matrimonii z 7 marca 1972 roku. Wspomina ona "o fachowej pomocy biegłych przy redakcji prośby o dyspensę papieską" ${ }^{4}$.

Według Normae S. Romanae Rotae Tribunalis opublikowanych 22 czerwca 1934 roku dowód procesowy z „opinii biegłego teologa występuje w sprawach o stwierdzenie nieważności sakramentu małżeństwa lub ka-

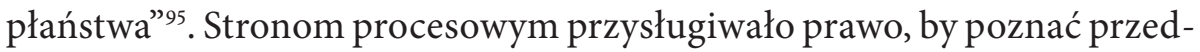
miot opinii biegłego oraz by zaproponować na jej temat swoje uwagi ${ }^{96}$.

93 „In iudiciali continuanda inquisitione eaedem cautelae serventur quoad testium personas et peritorum quoque, seu obstetricum. Huiusmodi cautelas studiosius, prouti qualitas personarum expostulat, observare oportet, quoties aut orator, aut pars conventa, aut testes aut periti ex commissione rogatoria apud aliam Curiam excutiendi sint. Quoties periti, obstetrices aut matrona, respective, quodam in examine partem habentes, personam explorandam personaliter cognoscant, adeo ut sit supervacaneum praefata documenta transmittere, de hac circumstantia in actis fides fiat. Peracto examine, dum peritis aut obstetricibus consueta interrogatoria fiunt, ad comparendum coram tribunali citetur etiam persona examini subiecta, ut de personae identitate interrogationes ei appositae fiant. Quod si persona comparere nolit aut non possit, de identitate ipsius experimento submissae aeque fiant interrogationes, habita ratione tum peritorum relationis, tum documentorum, quae ad hunc finem transmissa fuere, ut dictum est in $\$ 1$ ”. Normae observandae in processibus super matrimonio rato et non consummato ad praecavendam dolosam personarum substitutionem, s. 491, $1 \$ 4.2-\$ 4$; por. T. Rozkrut, Walor opinii biegłego..., dz. cyt., s. 115.

${ }^{94},[\ldots]$ in his quoque causis consiliariorum vel peritorum, praesertim ecclesiasticorum, opera utantur [...]". Instructio Dispensationis matrimonii. Instructio de quibusdam emendationibus circa normas in processu super matrimonio rato et non consummato servandas, s. 249. Por. T. Rozkrut, Walor opinii biegtego..., dz. cyt., s. 123.

95 „In causis validitatem matrimonii vel sacrae ordinationis respicientibus, si occurrant quaedam difficiliores circa theologiam quaestiones, Ponens aut Turnus unum vel plures peritos theologos ex officio eligere possunt, non requisita nec exspectata partium petitione. His peritis applicanda sunt, pro rei natura, quae ius de peritis statuit". Normae S. Romanae Rotae Tribunalis, s. 474, art. $97 \$ 1-2$. Por. T. Rozkrut, Walor opinii biegłego..., dz. cyt., s. 116.

${ }_{96}$ „Partes ius habent obiectum peritiae cognoscendi, antequam perficiatur, nisi agatur da causa criminali, vel etiam de gravi ordinis publici negotio, in quibus expediat partes de peritia certiores non facere nisi quando iam peracta fuerit. Partes, quibus obiectum futurae peritiae communicetur, opportunas animadversiones proponere possunt, etiam circa ipsum deputationis rescriptum". Normae S. Romanae Rotae Tribunalis, s. 474, art. $98 \$ 1-2$. Por. T. Rozkrut, Walor opinii biegłego..., dz. cyt., s. 116. 
Święte Oficjum 12 czerwca 1942 roku wydało dekret Qua singulari, który wskazywał na dowód $\mathrm{z}$ oględzin cielesnych $\mathrm{w}$ sprawach $\mathrm{z}$ tytułu impotencji i z tytułu małżeństw zawartych, ale niedopełnionych ${ }^{97}$. Dekret stwierdzał, że badanie cielesne małżonków, zwłaszcza kobiety, było niekonieczne, gdy niedopełnienie nastąpiło z braku czasu lub miejsca czy też kiedy kobieta podjęła współżycie seksualne z innym mężczyzną ${ }^{98}$. Według dekretu badanie kobiety można było opuścić, gdy materiał dowodowy był „przekonujący albo gdy mężczyzna był niezdolny do aktu seksualnego" "99. Do oględzin mężczyzny powinni być powołani biegli lekarze, natomiast w przypadku oględzin kobiety powinny być powołane 2 kobiety mające doktorat $\mathrm{z}$ nauk medycznych lub przynajmniej wykwalifikowane położne ${ }^{100}$.

Z dekretu wynika ponadto, że biegłe lekarki lub w ich zastępstwie dyplomowane akuszerki po skończonych oględzinach kobiety i napisaniu sprawozdania były przesłuchiwane przez sędziego według ułożonych pytań obrońcy węzła małżeńskiego. Przesłuchanie to miało być nie tylko w obecności notariusza, obrońcy węzła małżeńskiego i promotora sprawiedliwości, gdy brał udział w procesie, ale także w obecności uczciwego i religijnego lekarza specjalisty, który mógł „poczynić swoje uwagi na temat niemocy płciowej zbadanej kobiety i poddać sędziemu pytania

${ }^{97}$ Por. T. Rozkrut, Walor opinii biegłego..., dz. cyt., s. 119-120.

${ }^{98},[\ldots]$ si consummatio haberi non potuit quia nec tempus nec locus nec modus adfuerunt matrimonii consummandi; si iam constat de mulieris defloratione”. Decretum „Qua singulari" de quibusdam cautelis adhibendis in causis matrimonialibus impotentiae et inconsummationis, s. 201, n. 1. Por. T. Rozkrut, Walor opinii biegłego..., dz. cyt., s. 120.

${ }^{99}{ }$ His casibus alii duo addendi sunt, nempe: omitti poterit inspectio si, attenta partium et testium morali excellentia, ac serio pensatis eorum animi dispositionibus necnon ceteris adminiculis aut argumentis, Ordinarii iudicio, pienissima iam habeatur probatio de impotentia vel de inconsummatione; omittatur mulieris inspectio, si ex inspectione viri plene constiterit de huius incapacitate ad matrimonium consummandum”. Decretum „Qua singulari" de quibusdam cautelis adhibendis in causis matrimonialibus impotentiae et inconsummationis, s. 201. Por. T. Rozkrut, Walor opinii biegłego..., dz. cyt., s. 120.

${ }^{100}$ „Quoties ad necessariam probationem assequendam requiratur coniugum inspectio corporalis, ad inspiciendum virum deputentur periti medici, ad mulierem vero inspiciendam designentur (ad mentem can. 1979, 2) duae mulieres quae laurea doctorali in arte medica, vel saltem legitimo peritiae in arte obstetricia testimonio praeditae sint". Decretum "Qua singulari" de quibusdam cautelis adhibendis in causis matrimonialibus impotentiae et inconsummationis, s. 201, n. 1-2. Por. T. Rozkrut, Walor opinii biegłego..., dz. cyt., s. 120. 
konieczne ze stanowiska wiedzy medycznej"101. Lekarz specjalista, poważny wiekiem i bardzo uczciwy, miał podczas przesłuchania zadawać pytania szczegółowe kobiecie dotkniętej niemocą płciową. Lekarza w procesie o dyspensę od małżeństwa niedopełnionego wybierał ordynariusz ${ }^{102}$.

Omawiany dekret zwrócił uwagę, aby sędzia, obrońca węzła małżeńskiego, promotor sprawiedliwości uwzględniali kulturę słowa w czynnościach sądowych w sprawach $\mathrm{z}$ tytułu impotencji ${ }^{103}$.

W 1950 roku papież Pius xiI wydał dla Kościoła wschodniego motu proprio Sollicitudinem Nostram ${ }^{104}$. Normy zawarte w tym dokumencie odnośnie do biegłego w procesie kanonicznym są w zasadzie identyczne $\mathrm{z}$ odpowiednimi normami łacińskimi z kodeksu z 1917 roku $^{105}$.

${ }^{101}$ „Si vero praefatae mulieres ad inspectionem perficiendam haberi nequeant, tunc licitum erit Ordinario, de consensu mulieris inspiciendae, examen peragendum committere viris, qui tamen non tantum medica arte sint insignes, sed etiam religionis et honestatis laude commendati, moribus atque aetate graves, ab ipso Ordinario vel iudice moniti de christianae modestiae regulis sancte servandis; quique ad inspectionem ne deveniant nisi adstante honesta matrona ex ofticio designanda (can. 1979, 3). Si mulier aut inspectionem ipsam aut virorum operam recuset, abstinendum est ab urgenda inspectione vel ab exigendo virorum interventu; satis tunc erit illam monere de iuridicis suae recusationis consectariis, seu de graviori difficultate vel etiam de probabili impossibilitate assequendi sui propositi probationem”. Decretum "Qua singulari” de quibusdam cautelis adhibendis in causis matrimonialibus impotentiae et inconsummationis, s. 201, n. 3-4. Por. S. Biskupski, Prawo małżeńskie Kościoła rzymskokatolickiego, dz. cyt., s. 273.

${ }^{102}$ „Peracta per mulieres inspectione, earum orale examen fiat ab ipso Tribunali, semper tamen adstante medico in his rebus vere perito ac honestate claro, qui suas animadversiones et opportunas interrogationes proponere possit. Excussio mulieris, quae est pars in causa, paratis ad normam iuris interrogationibus eidem proponendis, semper quidem fiat coram Tribunali, sed a medico, qui sit religione, moribus, aetate gravis, ab ipso Ordinario deligendus, omni exceptione maior”. Decretum "Qua singulari” de quibusdam cautelis adhibendis in causis matrimonialibus impotentiae et inconsummationis, s. 201, n. 5-6. Por. S. Biskupski, Prawo małżeńskie Kościoła rzymskokatolickiego, dz. cyt., s. 273.

${ }^{103}$ „In exarandis sententiis in huiusmodi processibus, praesertim si hae publici iuris fieri debeant, abstinendum erit a nimia et minuta rerum descriptione: facta vero et rationes exponantur castigatis verbis”. Decretum „Qua singulari” de quibusdam cautelis adhibendis in causis matrimonialibus impotentiae et inconsummationis, s. 201, n. 7. Por. S. Biskupski, Prawo małżeńskie Kościoła rzymskokatolickiego, dz. cyt., s. 273.

${ }^{104}$ Pius XII, m.p. De iudiciis pro Ecclesia Orientali „Sollicitudinem Nostram”, AAS 42 (1950), s. 5-120 (w tym o biegłych s. 70-73).

${ }^{105}$ Por. T. Rozkrut, Walor opinii biegłego..., dz. cyt., s. 123; por. T. Rozkrut, Walor opinii biegłego..., dz. cyt., s. 120-122. 
Święta Kongregacja do spraw Sakramentów wypowiedziała się w Regulae servandae in processibus super nullitate sacrae ordinationis z 9 czerwca 1931 roku o udziale biegłych w procesie o nieważność święcen ${ }^{106}$. Dokument mówił m.in. o badaniu powoda przez 2 biegłych lekarzy powołanych z urzędu. Zobowiązani oni byli złożyć przysięgę „na rzetelność wykonanego zadania oraz na zachowanie tajemnicy odnośnie do stanu zdrowia psychicznego badanej osoby"107.

Papież Pius XI ustanowił 6 lutego 1930 roku sekcję historyczną przy Kongregacji Obrzędów, czyli stały zespół biegłych historyków jako konsultorów $^{108}$. Do spraw historycznych należało powoływać biegłych, którzy dobrze znali metody historyczne i byli kompetentni w archiwistyce ${ }^{109}$.

Normae speciales Najwyższego Trybunału Sygnatury Apostolskiej z 1968 roku mówiły m.in. o powoływaniu biegłych jako doradców dla rozwiązywania skarg w sprawach administracyjnych, które były skierowane do tego trybunału ${ }^{110}$.

${ }^{106}$ Sacra Congregatio de Sacramentis, Regulae servandae in processibus super nullitate sacrae ordinationis vel onerum sacris ordinibus inhaerentium a Sacra Congregatione de disciplina sacramentorum editae, AAS 23 (1931), s. 457-492 (zwłaszcza s. 464, 466). Por. T. Rozkrut, Walor opinii biegtego..., dz. cyt., s. 123.

${ }^{107}$ „Ad explorandum actorem physice, si casus ferat, duo periti medici ex officio deputari debent (can. $1979 \$ 1$ ) qui, praestito iureiurando, de manere fideliter implendo et de secreto servando monendi, erunt, ut artis praesidiis utantur ad dignoscendum statum actoris, et referant, iuxta medicinalis doctrinae placita, indicia seu argumenta, quae sacrorum ordinum vel onerum validitatem ex defectu mentis in actore adstruere aut excludere videantur". Regulae servandae in processibus super nullitate sacrae ordinationis vel onerum sacris ordinibus inhaerentium a Sacra Congregatione de disciplina sacramentorum editae, s. 471, n. 68. T. Rozkrut, Walor opinii biegłego..., dz. cyt., s. 123.

${ }^{108}$ Pius XI, m.p. Instituitur «Sectio Historica» penes Sacrorum Rituum Congregationem Già da qualche tempo, AAS 22 (1930), s. 87-88.

109 „Antequam Processus instituatur, Ordinarius, audito Fidei Promotore seu Fiscali, Commissionem instituat trium membrorum, quorum peritia circa historicas methodos et circa archivales investigationes omnino sit probata. His competit «in solidum» officium colligendi omnes fontes scriptos circa vitam, virtutes vel martyrium, antiquam famam sanctitatis vel martyrii, aut antiquum cultum Servi Dei”. Normae Servandae in construendis processibus ordinariis super causis historicis, s. 175. Por. T. Rozkrut, Walor opinii biegłego..., dz. cyt., s. 124.

${ }^{110}$ Secretaria Status, Normae speciales in Supremo Tribunali Signaturae Apostolicae ad experimentum servandae, EV 8 (1984), s. 580, art. $117 \S 3$; s. 584, art. $123 \$ 1$. Por. T. Rozkrut, Walor opinii biegtego..., dz. cyt., s. 124. 
Biegli Kongregacji Nauki Wiary mieli „wyrazić swoją opinię na temat zgodności niektórych poglądów teologicznych z nauką Kościoła”"11.

Jak można zauważyć, w przytoczonych powyżej dokumentach kościelnych doprecyzowano treść norm kanonicznych, których fundament stanowił Kodeks prawa kanonicznego z 1917 roku $^{112}$.

I.3. Ogólne zaprezentowanie działalności biegłych sądowych w procesach małżeńskich w Sądzie Diecezjalnym w Tarnowie w latach I945-I983

Poniżej w tabeli zaprezentowano dane statystyczne przedstawiające udział biegłych w sprawach małżeńskich w Sądzie Diecezjalnym w Tarnowie w latach 1945-1983. Został on ukazany na tle liczby spraw wpływających w danym roku do sądu oraz tytułów (przyczyn) nieważności małżeństwa w tych przypadkach, w których korzystano $\mathrm{z}$ ich ekspertyz. Zdarzało się, że w jednej sprawie brało udział 2 lub więcej biegłych sądowych.

${ }^{111}$ "Cardinalis Praefectus, Secretarius et, si hi absunt, Subsecretarius facultate praediti sunt concredendi, si res urgeat, votum alicui e Consultoribus; at Congressus solus peritum «ex commissione speciali» desygnat". Nova agendi ratio in doctrinarum examine, s. 234, n. 4. Por. T. Rozkrut, Walor opinii biegłego..., dz. cyt., s. 124.

${ }^{112}$ Por. T. Rozkrut, Walor opinii biegłego..., dz. cyt., s. 124. 


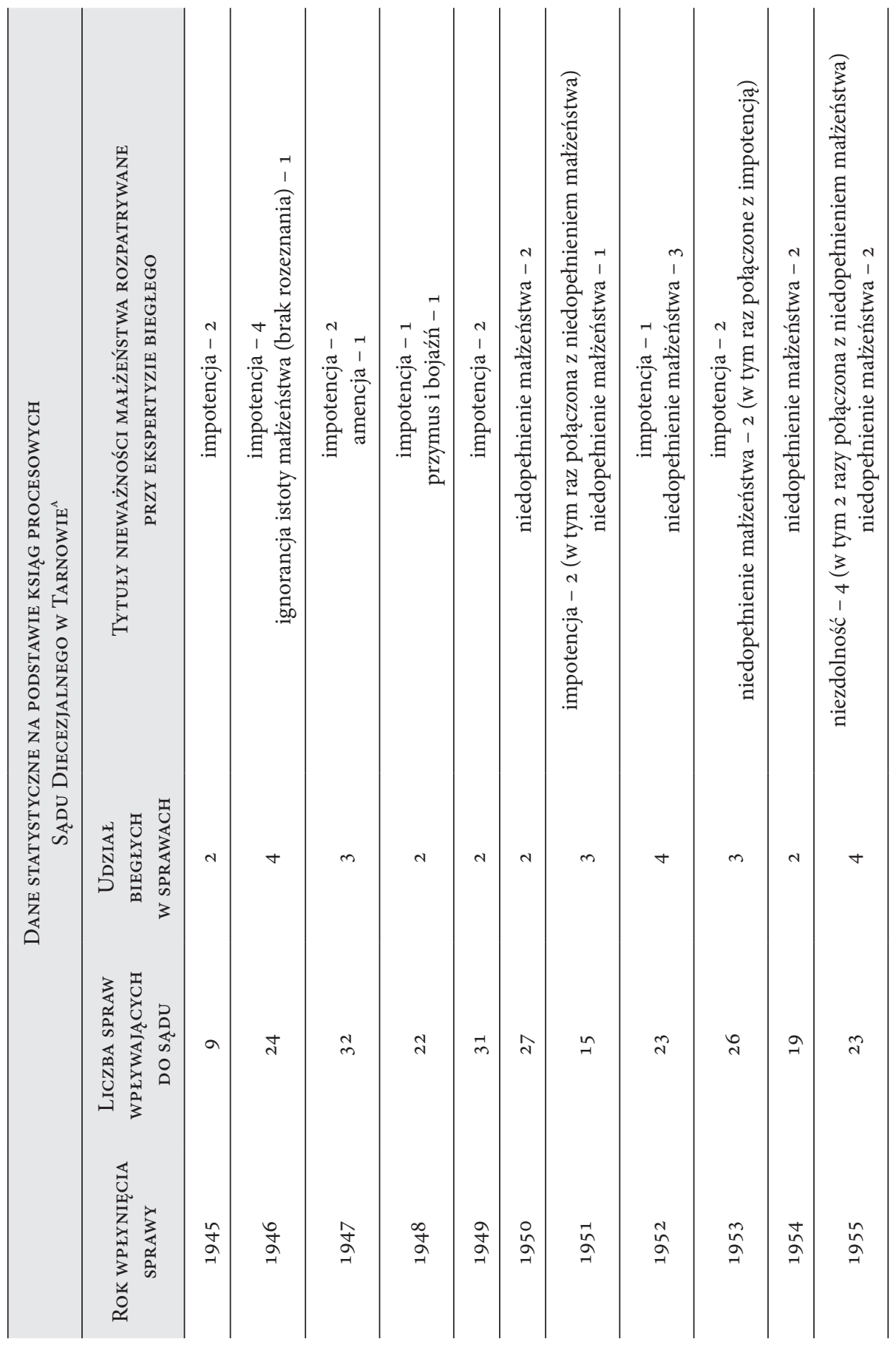




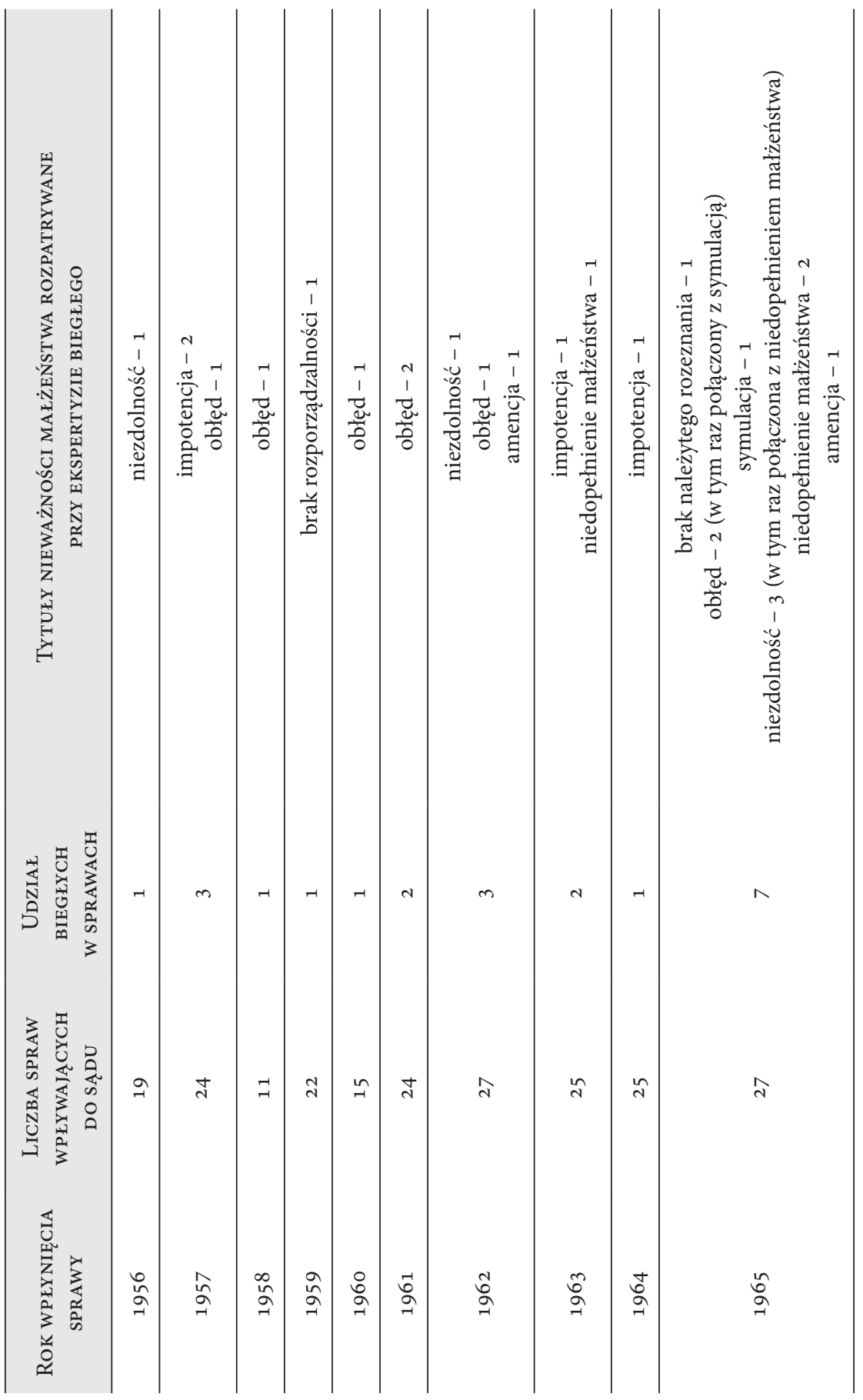




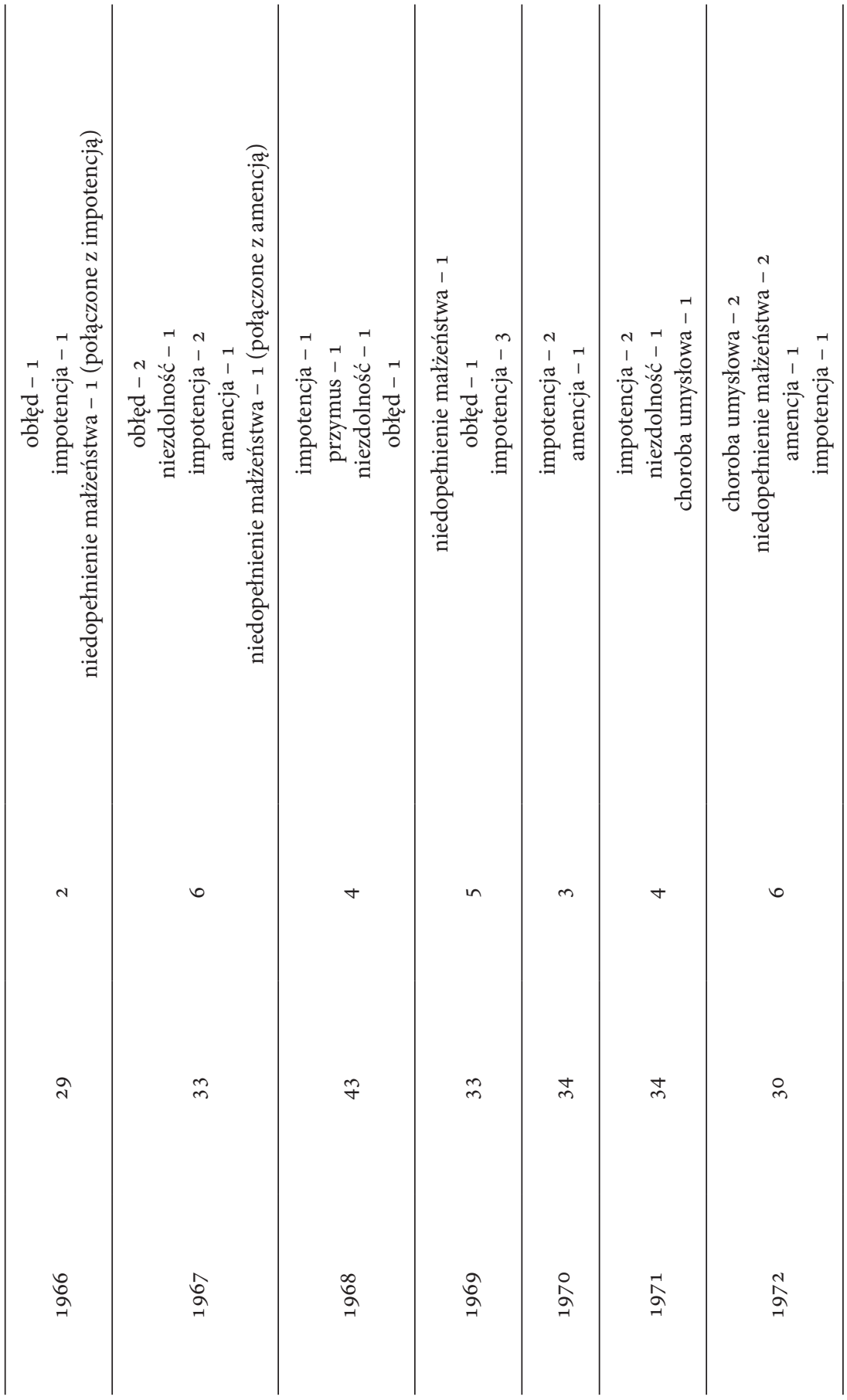




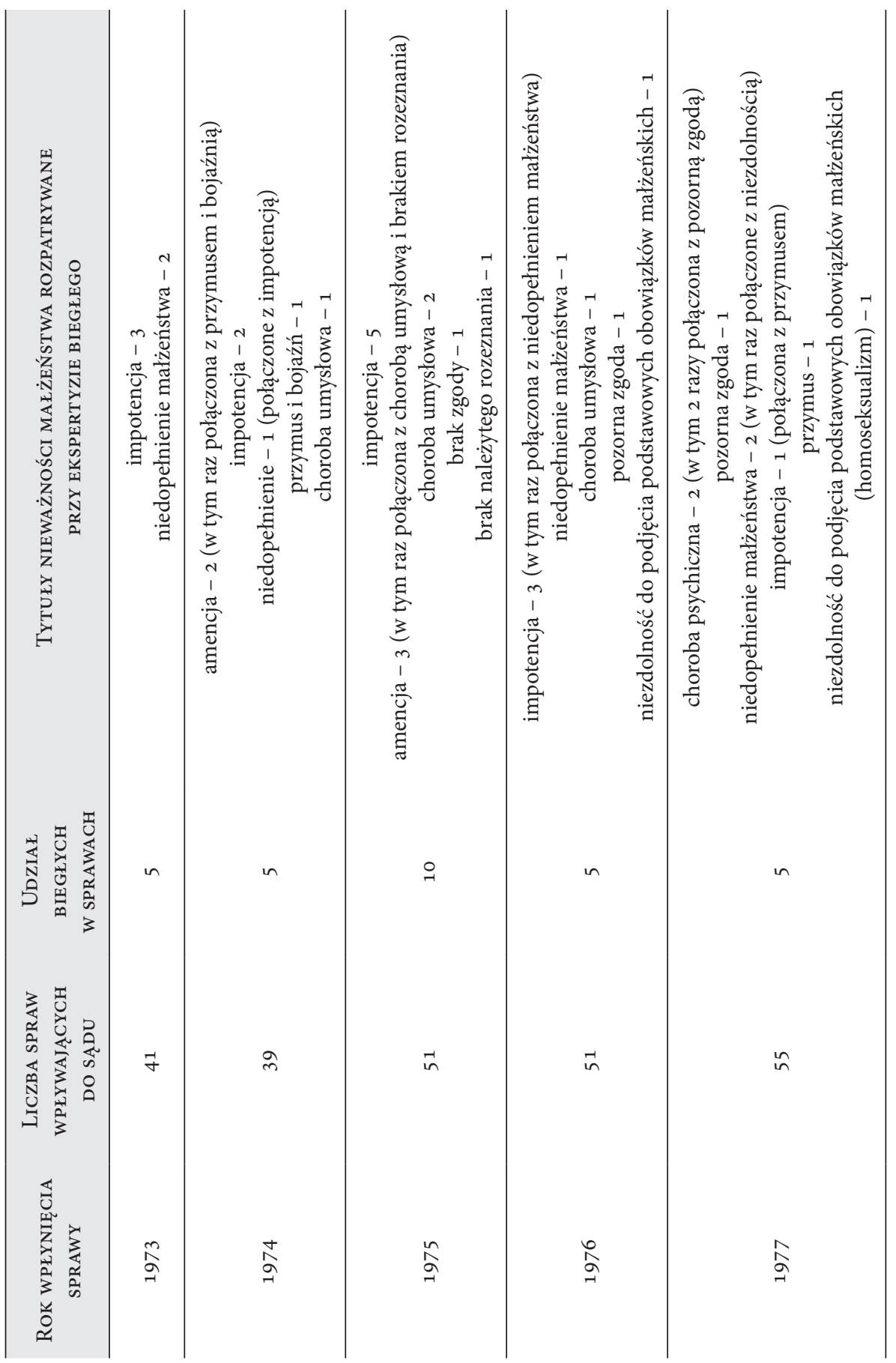




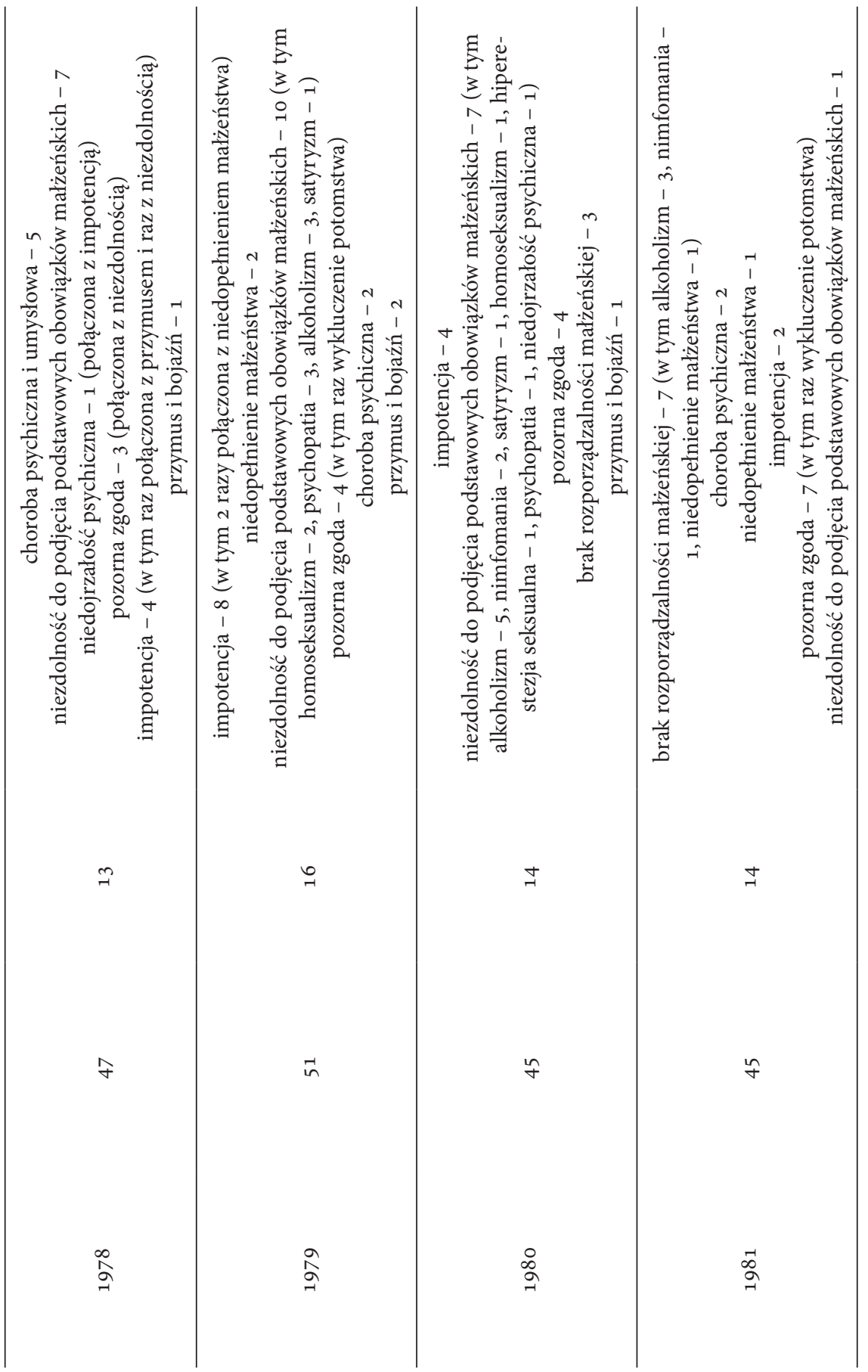




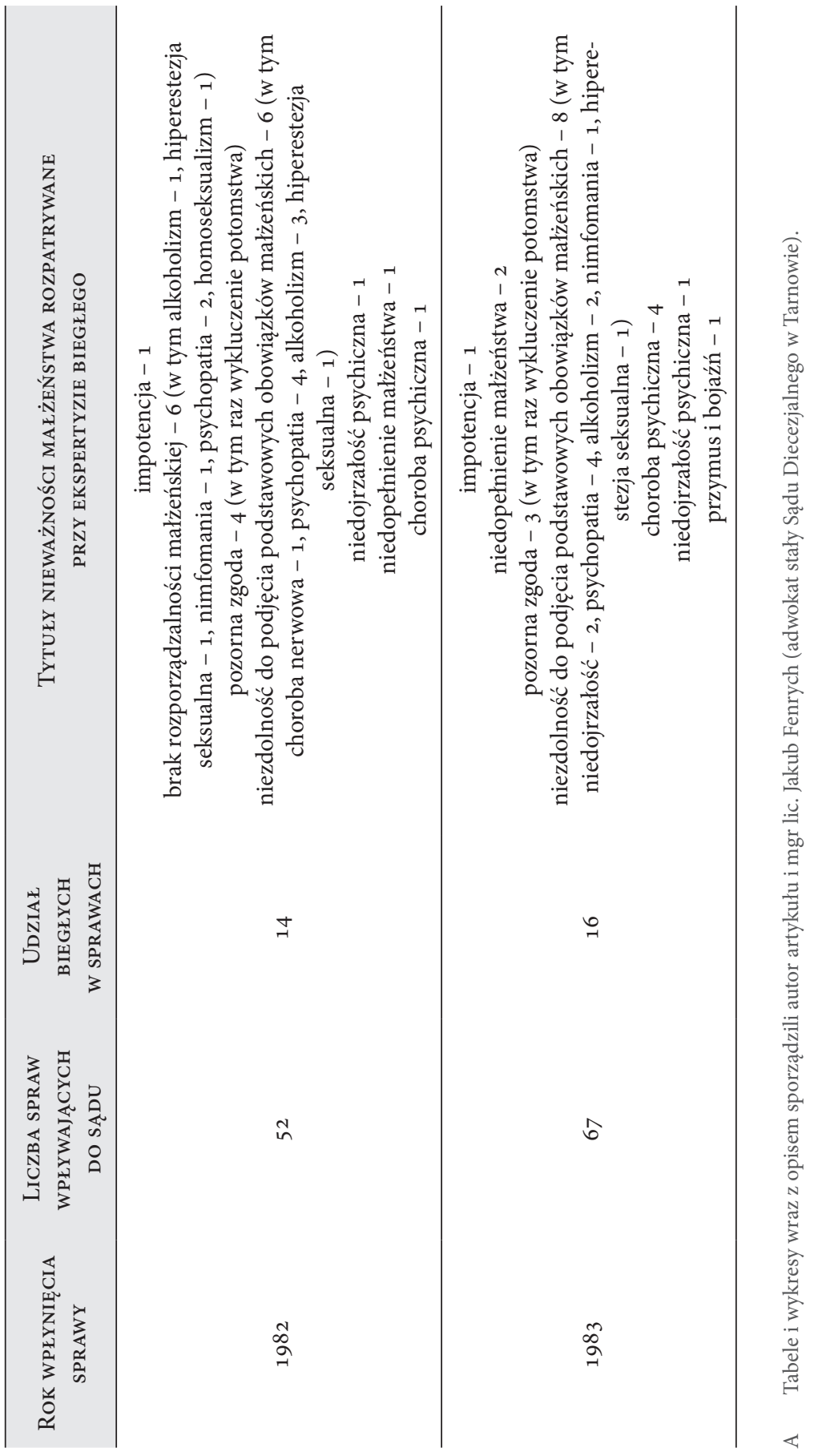



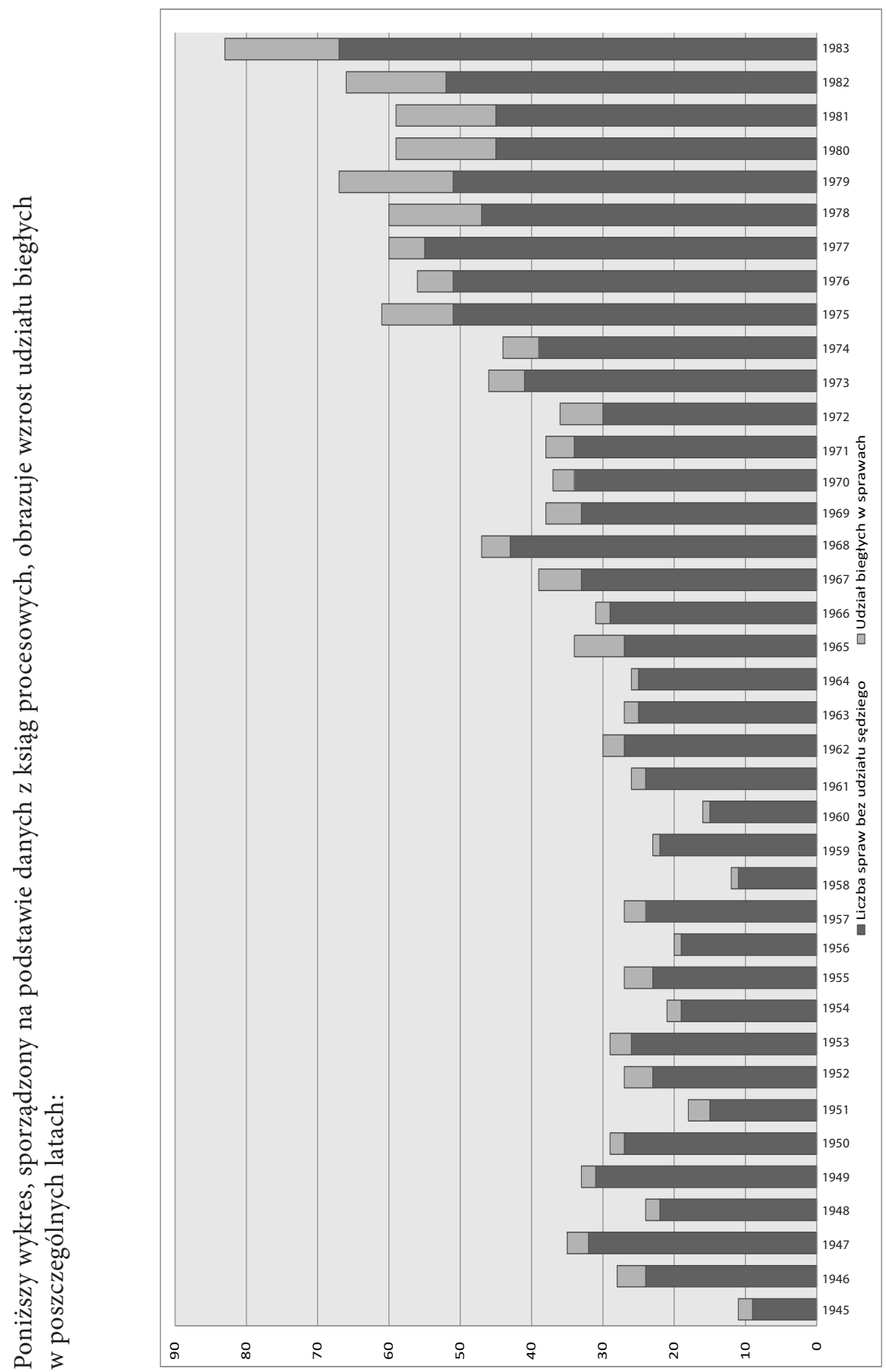
Wykres powyższy jednoznacznie wskazuje, iż wraz ze wzrostem wpływających spraw pojawiła się też konieczność częstszego korzystania z pomocy zaprzysiężonych przy trybunale biegłych.

Kolejny z wykresów przedstawia rodzaje tytułów nieważności małżeństwa oraz przypadki jego niedopełnienia, do których był powoływany biegły sądowy. Jak już zaznaczono wyżej, liczba tytułów nie jest równa liczbie powoływanych biegłych sądowych, albowiem bardzo często w omawianym okresie tytuły były ze sobą łączone. Najczęściej łączonymi tytułami były:

- impotencja i niedopełnienie małżeństwa;

- niezdolność do podjęcia obowiązków małżeńskich z impotencją;

- niezdolność do podjęcia obowiązków małżeńskich z pozorną zgodą;

- pozorna zgoda z chorobą psychiczną lub amencją.

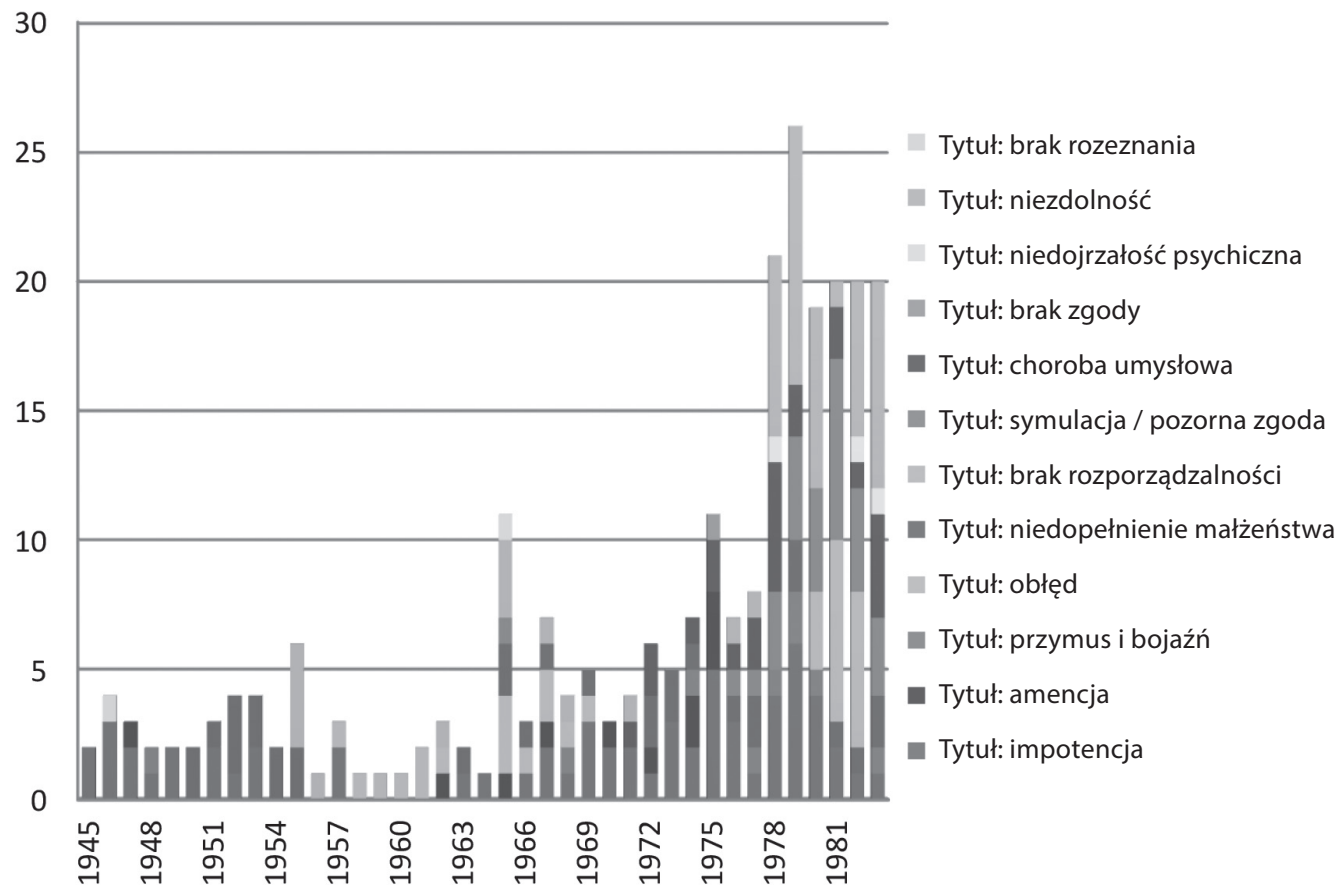


Analizując powyższe tabelę oraz wykresy, należy także zauważyć, że niektóre sprawy raz były klasyfikowane jako brak rozeznania co do istotnych obowiązków małżeńskich, a kiedy indziej jako niezdolność do podjęcia istotnych obowiązków małżeńskich czy brak rozporządzalności małżeńskiej. Przykładem są tu głównie lata 1979-1983.

W 1979 roku do tytułu niezdolności do podjęcia istotnych obowiązków małżeńskich wliczane były: homoseksualizm - 2, psychopatia - 3, alkoholizm - 3, satyryzm - 1 i podobnie w 1980 roku, kiedy kwalifikowano niezdolność w następujących przypadkach: alkoholizm - 5, nimfomania -2 , satyryzm -1 , homoseksualizm -1 , hiperestezja seksualna -1 , psychopatia - 1, niedojrzałość psychiczna - 1. Natomiast w 1981 roku do braku rozporządzalności małżeńskiej oprócz innych przyczyn wliczane były: alkoholizm - 3, nimfomania - 1, niedopełnienie małżeństwa - 1. W 1982 roku do braku rozporządzalności małżeńskiej wliczane były: alkoholizm - 1, hiperestezja seksualna - 1, nimfomania - 1, psychopatia -2 , homoseksualizm -1 , a do niezdolności do podjęcia istotnych obowiązków małżeńskich: choroba nerwowa - 1, psychopatia - 4, alkoholizm - 3, hiperestezja seksualna - 1, niedojrzałość psychiczna - 1. W 1983 roku zanikła kategoria braku rozporządzalności małżeńskiej, a pozostała tylko kategoria niezdolności do podjęcia istotnych obowiązków małżeńskich, do której zaliczano: niedojrzałość - 2, psychopatię - 4, alkoholizm - 2, nimfomanię - 1, hiperestezję seksualną - 1 .

Poniższa tabela przedstawia procentowy udział biegłych w sprawach toczących się w Sądzie Diecezjalnym w Tarnowie w latach 1945-1983.

\begin{tabular}{cccc}
\hline $\begin{array}{c}\text { Rok przyjęcia } \\
\text { sprawy }\end{array}$ & $\begin{array}{c}\text { Liczba spraw wpły- } \\
\text { wających do sądu }\end{array}$ & $\begin{array}{c}\text { Udział biegłych } \\
\text { w sprawach }\end{array}$ & $\begin{array}{c}\text { Udział biegłych } \\
\text { w sprawach w \% }\end{array}$ \\
\hline 1945 & 9 & 2 & 22,22 \\
\hline 1946 & 24 & 4 & 16,67 \\
\hline 1947 & 32 & 3 & 9,38 \\
\hline 1948 & 22 & 2 & 9,09 \\
\hline 1949 & 31 & 2 & 6,45 \\
\hline 1950 & 27 & 2 & 7,41 \\
\hline 1951 & 15 & 3 & 15,00 \\
\hline
\end{tabular}




\begin{tabular}{|c|c|c|c|}
\hline $\begin{array}{l}\text { Rok przyjęcia } \\
\text { sprawy }\end{array}$ & $\begin{array}{l}\text { Liczba spraw wpły- } \\
\text { wających do sądu }\end{array}$ & $\begin{array}{l}\text { Udział biegłych } \\
\text { w sprawach }\end{array}$ & $\begin{array}{l}\text { Udział biegłych } \\
\text { w sprawach w \% }\end{array}$ \\
\hline 1952 & 23 & 4 & 17,39 \\
\hline 1953 & 26 & 3 & 11,54 \\
\hline 1954 & 19 & 2 & 10,53 \\
\hline 1955 & 23 & 4 & 17,39 \\
\hline 1956 & 19 & 1 & 5,26 \\
\hline 1957 & 24 & 3 & 12,50 \\
\hline 1958 & 11 & 1 & 9,09 \\
\hline 1959 & 22 & 1 & 4,55 \\
\hline 1960 & 15 & 1 & 6,66 \\
\hline 1961 & 24 & 2 & 8,33 \\
\hline 1962 & 27 & 3 & 11,11 \\
\hline 1963 & 25 & 2 & 8,00 \\
\hline 1964 & 25 & 1 & 4,00 \\
\hline 1965 & 27 & 7 & 25,93 \\
\hline 1966 & 29 & 2 & 6,90 \\
\hline 1967 & 33 & 6 & 18,18 \\
\hline 1968 & 43 & 4 & 9,30 \\
\hline 1969 & 33 & 5 & 15,15 \\
\hline 1970 & 34 & 3 & 8,82 \\
\hline 1971 & 34 & 4 & 11,76 \\
\hline 1972 & 30 & 6 & 20,00 \\
\hline 1973 & 41 & 5 & 12,19 \\
\hline 1974 & 39 & 5 & 12,82 \\
\hline 1975 & 51 & 10 & 19,61 \\
\hline 1976 & 51 & 5 & 9,80 \\
\hline 1977 & 55 & 5 & 9,09 \\
\hline 1978 & 47 & 13 & 27,66 \\
\hline
\end{tabular}




\begin{tabular}{cccc}
\hline $\begin{array}{c}\text { Rok przyjęcia } \\
\text { sprawy }\end{array}$ & $\begin{array}{c}\text { Liczba spraw wpły- } \\
\text { wających do sądu }\end{array}$ & $\begin{array}{c}\text { Udział biegłych } \\
\text { w sprawach }\end{array}$ & $\begin{array}{c}\text { Udział biegłych } \\
\text { w sprawach w \% }\end{array}$ \\
\hline 1979 & 51 & 16 & 31,37 \\
\hline 1980 & 45 & 14 & 31,11 \\
\hline 1981 & 45 & 14 & 31,11 \\
\hline 1982 & 52 & 14 & 26,92 \\
\hline 1983 & 67 & 16 & 23,88 \\
\hline
\end{tabular}

Z powyższej tabeli sporządzonej na podstawie ksiąg procesowych wynika, iż procentowy udział biegłych wahał się w badanym okresie od 4,oo proc. (w 1964 roku) do 31,37 proc. (w 1979 roku). Średni udział biegłych w latach $1945-1983$ to 14,47 proc. W ostatnich latach badanego okresu, tj. 1978-1983, udział biegłych oscylował już w zakresie od jednej czwartej do jednej trzeciej procesów.

Konkludując analizę tabel i wykresów, należy zauważyć nie tylko wzrost liczby wpływających do Sądu Diecezjalnego w Tarnowie spraw małżeńskich, ale przede wszystkim proporcjonalny wzrost udziału biegłych w tych sprawach. Najczęściej udział biegłych wynosił kilkanaście procent.

\section{I.3.I. LISTA BIEGEYCH WYSTĘPUJĄCYCH W SPRAWACH MAEŻEŃSKICH} w Sądzie Diecezjalnym w Tarnowie w latach i945-I983

Na przestrzeni badanego okresu najczęściej powoływanymi biegłymi Sądu Diecezjalnego, wprost wymienianymi w księgach procesowych ${ }^{113}$, byli:

1. lekarz medycyny Karol Zięba - specjalista chorób wewnętrznych (1950 rok);

2. doktor medycyny Edmund Kowalski;

3. doktor medycyny Stanisław Krajewski - specjalista chorób skórnych, wenerycznych;

${ }^{113}$ Przedstawiana lista nie wyczerpuje pełnego zakresu powoływanych biegłych. Zestaw ten został zaprezentowany na podstawie ksiąg procesowych i niektórych akt spraw. Pełna lista wymagałaby szerszych badań wyłącznie na podstawie akt procesowych. Daty umieszczone w nawiasach przy nazwiskach biegłych wskazują na rok, od którego dany biegły pojawiał się w księgach procesowych. Przy niektórych biegłych nie jest możliwe określenie tej daty. Przy tworzeniu listy zachowano pisownię zawartą w księgach procesowych. 
4. doktor medycyny Roman Piotrowski - specjalista chorób skórnych, wenerycznych, płciowych;

5. lekarz profesor A.M. Stanisław Liebhart - specjalista w położnictwie i ginekologii;

6.doktor medycyny Marian Ciećkiewicz - specjalista chorób wewnętrznych i orzecznictwa (1963 rok);

7. doktor medycyny Józef Horodeński - specjalista chorób nerwowych i umysłowych (1962 rok);

8. doktor medycyny Jan Anyszek (1965 rok);

9. doktor medycyny Wanda Półtawska - specjalista psychiatra (1965 rok);

10. lekarz medycyny Kazimierz Gomółka - specjalista chorób zakaźnych i wewnętrznych (1967 rok);

11. lekarz medycyny Anna Zołoteńko - specjalista psychiatra (1970 rok);

12. doktor medycyny Halina Sawicka - specjalista psychiatra (1972 rok);

13. lekarz medycyny Aniela Malik - specjalista chorób psychicznych (1974 rok);

14. lekarz medycyny Maria Skaza - specjalista w zakresie chorób wewnętrznych (1975 rok);

15. lekarz medycyny Joanna Walewska - specjalista w zakresie chorób wewnętrznych (1975 rok);

16. lekarz medycyny Róża Landwójtowicz - specjalista chorób psychicznych (1978 rok);

17. lekarz medycyny Jan Tomik - specjalista ginekolog - położnik;

18. lekarz medycyny Ewa Chrapusta-Witek - specjalista ginekolog położnik;

19. lekarz medycyny Andrzej Kowal - specjalista psychiatra;

20. magister Irena Gancarz - psycholog;

21. magister Jacek Skrobot - psycholog kliniczny.

Należy zauważyć, że w pierwszej części badanego okresu biegłymi powoływanymi do procesów małżeńskich byli głównie lekarze medycyny, zwłaszcza specjaliści z zakresu ginekologii i psychiatrii. W drugiej części badanego okresu znacznie częściej powoływani byli biegli z zakresu psychologii. Związane jest to zwłaszcza z rozwojem nauk technicznych i przyrodniczych oraz humanistycznych, a przede wszystkim $\mathrm{z}$ rozwojem psychologii ${ }^{114}$.

${ }^{114}$ „Niewątpliwie rola biegłego wzrastała powoli. Była prawnie kształtowana i wzmacniana, szczególnie mocno w xx stuleciu, co było związane przede wszystkim z rozwojem 
Zdarzały się przypadki, iż w procesach małżeńskich w pierwszej instancji nie było powoływanych biegłych w sprawach z tytułu impotencji i niezdolności do podjęcia i wypełnienia istotnych obowiązków małżeńskich. Przykładem tego jest sprawa z roku 1983 (sygn. 1063).

Jak wspomniano w pierwszej części artykułu, przy badaniach ginekologiczno-seksuologicznych wymagana była obecność osoby czuwającej nad przeprowadzeniem badania kobiety zgodnie z zasadą moralności. Przykładem na to jest sprawa o impotencję po stronie kobiety z roku 1980 (sygn. 1449), kiedy została powołana przez trybunał poważana i godna zaufania matrona - instruktorka diecezjalnego duszpasterstwa rodzin.

\section{Zakończenie}

Praca biegłych sądowych w Sądzie Diecezjalnym w Tarnowie w latach 1945-1983 była oparta na normach Kodeksu prawa kanonicznego z 1917 roku i dokumentów pokodeksowych ${ }^{115}$. Biegli byli powoływani w sprawach małżeńskich zwłaszcza z tytułów impotencji, niedopełnienia małżeństwa i defektu zgody małżeńskiej ze względu na chorobę umysłową ${ }^{116}$. Akta sądowe były przekazywane $\mathrm{z}$ reguły 1 biegłemu lub 2 biegłym w celu wydania opinii. Gdy w przypadku 2 biegłych opinie były rozbieżne, sąd powoływał dla wyjaśnienia kwestii trzeciego biegłego („najbieglejszego”, "superbiegłego"). W przypadku sądu tarnowskiego w latach 1945-1983 był nim najczęściej doktor medycyny Marian Ciećkiewicz ${ }^{117}$. Po wstępnych pisemnych opiniach biegłych byli oni następnie przesłuchiwani przez

nauki i techniki oraz z rosnącą zdolnością i kompetencją naukowo-techniczną samego biegłego w daniu skutecznej pomocy w prawidłowym administrowaniu sprawiedliwości".

T. Rozkrut, Walor opinii biegłego..., dz. cyt., s. 124-125.

${ }^{115}$ Dokumenty te zostały wymienione w pierwszej części artykułu.

${ }^{116}$ Szczegółowe omówienie motywów prawnych nieważności małżeństwa w okresie po CIC 1917 oraz praktyczne sposoby ich udowadniania - por. W. Szafrański, Motywy prawne $w$ sprawach o nieważność matżeństwa rozpatrywanych przez sądy kościelne, Włocławek 1952; W. Szafrański, Motywy prawne w sprawach małżeńskich rozpatrywanych przez sądy Kościoła rzymsko-katolickiego, Włocławek 1966.

${ }^{117}$ Przykładowo w 1973 w sprawie (sygn. 1096) z tytułu niedopełnienia po opinii 2 biegłych akta zostały skierowane do doktora Mariana Ciećkiewicza jako trzeciego biegłego w celu rozstrzygnięcia opinii. W 1974 w 2 sprawach (sygn. 1115 i 1151) z tytułów impotencji i niedopełnienia po 2 rozbieżnych opiniach biegłych odwołano się do trzeciego eksperta, którym był także doktor Marian Ciećkiewicz. 
sędziego według pytań ułożonych przez obrońcę węzła małżeńskiego, który zapoznawał się wcześniej z tymi opiniami. Gwarantowało to rzetelność i obiektywność ekspertyz ${ }^{118}$.

Na zakończenie należy zauważyć, że rola biegłego w procesach małżeńskich stale wzrastała, a obecnie $\mathrm{w}$ wielu przypadkach nie ma możliwości zbadania ważności małżeństwa lub kwestii jego niedopełnienia bez udziału osoby sprawującej tę funkcję $e^{119}$.

${ }^{118}$ Praktyczne przeprowadzenie dowodu $\mathrm{z}$ opinii biegłych w przypadku impotencji (osobny wzór pytań skierowanych do biegłych odnośnie do impotencji u mężczyzny i odnośnie do impotencji u kobiety; pytania do przesłuchania matrony; wzór sprawozdania sądowo-lekarskiego sporządzony przez biegłego) - por. W. Szafrański, Przeszkoda impotencji w prawie kanonicznym, Włocławek 1964, s. 377-382.

${ }^{119}$ Obraz dalszego rozwoju pracy biegłego sądowego i jego znaczenia po 1983 w kościelnych procesach małżeńskich został omówiony przez autora artykułu w: J. Bednarz, Ogólne spojrzenie na udział biegłych sądowych w procesach o stwierdzenie nieważności matżeństwa $w$ Sądzie Diecezjalnym w Tarnowie w latach 1983-2015, w: Struktura i działalność Sądu Diecezjalnego w Tarnowie w latach 1983-2015, red. R. Kantor, Kraków 2016, s. 41-53. 